\title{
Economic and socio-cultural consequences of changing political rule on human and faunal diets in medieval Valencia (c. fifth-fifteenth century $A D$ ) as evidenced by stable isotopes
}

\author{
Michelle M. Alexander ${ }^{1}$ (D) $\cdot$ Alejandra Gutiérrez ${ }^{2} \cdot$ Andrew R. Millard $^{2} \cdot$ Michael P. Richards $^{3} \cdot$ Christopher M. Gerrard $^{2}$
}

Received: 26 July 2018 / Accepted: 12 February 2019 / Published online: 7 March 2019

(C) The Author(s) 2019

\begin{abstract}
This paper explores the impact of changing religious political rule on subsistence within a single city through time using stable isotope analysis of human and animal bone collagen. The diet and economy of the medieval city of Valencia (Spain) are examined over a 1000-year period during successive periods of Visigothic, Muslim and Christian rule. Bulk stable isotope analysis of carbon $\left(\delta^{13} \mathrm{C}\right)$ and nitrogen $\left(\delta^{15} \mathrm{~N}\right)$ was carried out on 67 humans and 47 animals sampled from several archaeological sites dating between the fifth and fifteenth centuries AD. Terrestrial $\mathrm{C}_{3}$ resources dominated the diet in all periods. However, an increase in consumption of $\mathrm{C}_{4}$ plants (e.g. millet, sorghum) and/or marine resources is detected among individuals dating to the Islamic period. Differences in the isotopic values of humans and animals between the three periods indicate a significant dietary diversity during the Islamic phases (eleventh to thirteenth century), compared with the earlier Visigothic phase (fifth-seventh century) and the later Christian phase (fourteenth and fifteenth century). Observed diachronic changes in isotopic results provide evidence for a shift in diet and subsistence, particularly during the Muslim and later Christian periods. This is linked with change in population and economic focus. Dietary diversity among Muslim individuals is hypothesised to indicate the polyculture that was reflected in varied Islamic agricultural practices and the presence of potential migrants from elsewhere in the Islamic world.
\end{abstract}

Keywords Muslim $\cdot$ Christian $\cdot$ Visigothic $\cdot$ Spain $\cdot$ Collagen $\cdot$ Diet

The influence of socio-political and economic change on diet over the long term is just beginning to be directly investigated using isotope analysis. Investigations have centred on a single location, such as the city of York (Müldner and Richards

Electronic supplementary material The online version of this article (https://doi.org/10.1007/s12520-019-00810-x) contains supplementary material, which is available to authorized users.

Michelle M. Alexander

michelle.alexander@york.ac.uk

1 BioArCh, Department of Archaeology, University of York, Environment Building 2nd Floor, Wentworth Way, Heslington, York YO10 5DD, UK

2 Department of Archaeology, Durham University, Durham, UK

3 Department of Archaeology, Simon Fraser University, Burnaby, BC, Canada
2007), or multiple sites across a large area, e.g. in Croatia (Lightfoot et al. 2012) and Mallorca (Fuller et al. 2010). Such studies have highlighted human dietary responses to these shifts. Recent work has, however, emphasised resilience and continuity in dietary practice despite dramatic shifts in socio-political circumstances, e.g. Christianisation in Poland (Reitsema et al. 2017). The present research explores the dietary impact of the major religious, socio-political, economic and population transformations that occurred over 1000 years in the medieval city of Valencia at the level of an individual. Both human and animal remains were analysed to examine aspects of day-to-day subsistence, agriculture and animal husbandry under Visigothic, Islamic and subsequent Christian control in eastern Spain.

During the medieval period, the Iberian Peninsula harboured a multi-faith society that was subject to dramatic socio-cultural, economic and demographic shifts associated with changes in religious political rule. The long and eventful 
settlement history of Valencia, a major city in Spain during the medieval period, provides the ideal opportunity to investigate the diet of its urban population over the long term in the context of these changes. In this article, we explore a period of roughly 1000 years from the fifth to the fifteenth centuries AD through the analysis of carbon $\left(\delta^{13} \mathrm{C}\right)$ and nitrogen $\left(\delta^{15} \mathrm{~N}\right)$ isotopes in collagen from human and animal bone: these samples are taken from multiple sites across the medieval city. The application of isotopic methodologies to medieval populations is growing in Spain, with many concentrating on Islamic populations (e.g. Salazar-García et al. 2014, 2016; Pickard et al. 2017; Guede et al. 2017), status (Jiménez-Brobeil et al. 2016), the Christian North (e.g. Sirignano et al. 2014) or the interplay of faith and diet between contemporaneous populations of Christians and Muslims under later Christian rule (Alexander et al. 2015). Although others have explored diachronic changes in diet in Spain, for example following the Islamic conquest in the Balearic Islands (Fuller et al. 2010), this is the first time any bioarchaeological analysis of historic diet has investigated such an extended chronology for any major Spanish city and in particular the transition from Islamic to Christian rule.

\section{Development of the medieval city}

The city of Valencia lies on the banks of the River Turia on Spain's Mediterranean coastline (Fig. 1). Founded in 138 BC, the Roman city of Valentia declined in importance during the Visigothic period (fifth-eighth century) but maintained its strategic value as the see of a Bishopric and remained the administrative nucleus of a wide territory (Ribera 2006, 2008; Jiménez Salvador 2009). In AD 711, the city was taken by Muslims and became fully established with an Islamic ruler in AD 800. After Rodrigo Díaz de Vivar ('El Cid') briefly interrupted Islamic rule, Valencia was re-taken by the Almoravids in AD 1109 and remained under Islamic control (Kennedy 1996). In 1238, Valencia fell to the Aragonese King James I and was annexed to the Crown of Aragón. The city now became capital of the Kingdom of Valencia between Murcia and the Tortosa region of the Ebro valley. Throughout the thirteenth and fourteenth centuries, the city was populated by Christian immigrants from the northern territories of Aragón (Guinot 2009, p. 176). Muslims who stayed in the area moved to a morería or Muslim quarter established outside the walls of Valencia (Baydal and Esquilache 2014).

\section{Economy and agriculture}

Throughout the medieval period, Valencia was an important port and commercial centre. By the twelfth century, Genoese merchants used the city to export goods from al-Andalus (the area of the Iberian Peninsula under Islamic control) to Christian ports throughout the Mediterranean (Constable 1994, p. 20). Agriculture, however, was at the heart of the region's economy and the changes to the ethnic and religious make-up of the population and shifting political power outlined above would have had a dramatic effect on agriculture, economy and diet. Agrarian transformation occurred across the Iberian Peninsula under Islamic rule. This 'agricultural revolution' (first coined as such by Watson in 1974, but see Decker 2009 and Squatriti 2014 for criticism) has been attributed to societal change and formation of a tributary economy, innovations in agricultural and hydraulic technology and the introduction of new crops, such as pomegranate, rice, cotton, sorghum and citrus fruits (Ruas et al. 2017). There is little evidence for a revolution in the archaeobotanical record so far, but the study of medieval plant remains has lagged behind that of the prehistoric periods in Spain (Peña-Chocarro et al. 2017).

The extensive irrigated area that surrounds Valencia today (known as the Horta) has its origins in the Islamic conquest of the eighth century (Guinot and Esquilache 2017). The development of intensive irrigation enabled the cultivation of a variety of crops at any given time and agricultural diversity in particular was a defining feature of the Islamic agrarian economy (Glick 1995). The introduction of sorghum (a $\mathrm{C}_{4}$ crop) in particular might be visible through isotopic data if it not yet archaeologically. The later Christian conquest saw the establishment of a feudal society and the reorganisation of cultivated land (Torró 2012a, b). Irrigation was maintained; however, new systems emerged, and the Horta was extended, while vines and cereal crops, particularly wheat, received new emphasis. There was also an increased emphasis on stock keeping and this period in particular saw the rise of longrange transhumance (Guinot and Esquilache 2017; Guinot 2009; Torró 2009).

Zooarchaeological data from sites across the Iberian Peninsula indicate that sheep/goat were the most common species at both Islamic and Christian period sites. Variation in kill-off patterns suggests that younger meat was preferred in the Islamic period, but these animals were increasingly used for secondary resources in the Christian period (e.g. wool). Conversely, cattle seem to have undergone the reverse trend (Morales et al. 2011). Pigs have been reported at Islamic period sites, although in low frequencies compared to Christian sites (Morales et al. 2011; Grau-Sologestoa 2017). These generalisations however belie the diversity of animal management practiced in the medieval period; there is no clear 'Muslim' signal for a zooarchaeological assemblage, although an urban/rural divide does appear to exist in the data (Morales et al. 2011; Grau-Sologestoa 2017; EstacaGómez et al. 2018). Large-scale shifts in agriculture and stock keeping have the potential to be read from the 


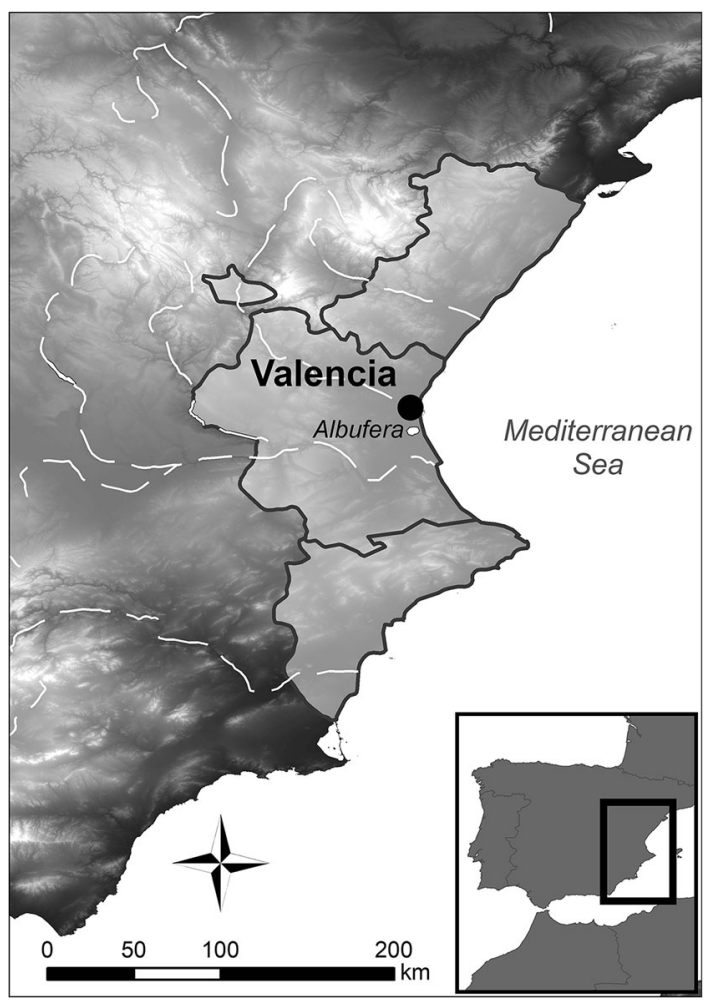

Fig. 1 Location map of Valencia. Map created with data from Natural Earth and the Shuttle Radar Topography Mission (SRTM)

isotopic data, providing direct evidence for discernible shifts in diet and economy that would be applicable at the individual and population level.

\section{Medieval diet}

A brief historical and archaeological overview of medieval diet in Spain is provided by Alexander et al. (2015) (but see also, for example, de Castro 1993; García Sánchez 1996, 2002; Adamson 2004). Wheat, a $\mathrm{C}_{3}$ crop, was the most desirable grain, although mixed-grain bread would have been the most commonly eaten; $\mathrm{C}_{4}$ crops such as millet (broomcorn and/or foxtail) or, from the Islamic period, sorghum, were considered secondary. These crops tended to be relied upon particularly in times of scarcity or by those of lower social status (de Castro 1993 p. 286; García Sánchez 2002, p. 279). A wide range of vegetables and fruit were also available from markets and kitchen gardens, but these contribute little in terms of the isotopic evidence considered here. Meat and dairy products made up a smaller, but important, part of the diet according to social status, geographical location/ environment and faith. Lamb and mutton were the most commonly consumed meats throughout the medieval period, and beef, chicken, pork (in the case of Christians) and game could also be found on the table (Waines 1992; de Castro 1993; García Sánchez 1996).
Freshwater and/or marine resources provided a valuable supplement to terrestrial resources and fish was often dried, salted, smoked or pickled (Gallart et al. 2005). Fish also served a liturgical requirement for Christians, who were obliged to avoid meat when fasting for a third of the year (Tomás 2009, p. 465). It is possible that a discernible increase in fish consumption might be detected in the later Christian population in line with religious doctrine, although alternatives, such as eggs, could have also been used instead (Gerrard 2003, p. 301). Consumption of terrestrial animal protein, marine resources and $\mathrm{C}_{3}$ and $\mathrm{C}_{4}$ plants, particularly if the latter were fed to animals whose products were consumed by humans, will all have an impact on the carbon and nitrogen isotope signature of consumer bone collagen.

\section{Stable isotope analysis}

In-depth reviews of stable isotopes and dietary reconstruction of archaeological populations are available elsewhere (e.g. Katzenberg 2000; Lee-Thope 2008; Schwarcz and Schoeninger 2011). In general terms, the composition of carbon and nitrogen isotopes in bone collagen is representative of a long-term average of the main protein sources of the diet in the decades before death, where protein intake is adequate (Hedges 2004; Hedges et al. 2007). The use of carbon isotopes to distinguish between the consumption of common, temperate $C_{3}$ crops and arid-adapted $C_{4}$ plants (O'Leary 1981) is notable in the context of medieval Spain where $\mathrm{C}_{4}$ crops such as millet, sorghum and sugarcane were present. $\delta^{13} \mathrm{C}$ values also differ between marine and terrestrial environments (Schoeninger and DeNiro 1984).

Nitrogen isotope ratios depend on the position of an organism within the food chain. It is widely accepted that $\delta^{15} \mathrm{~N}$ values increase 3-5\% between trophic levels (Bocherens and Drucker 2003), although spacing of up to $6 \%$ has been suggested for humans (O'Connell, et al. 2012). There is also a slight increase in $\delta^{13} \mathrm{C}$ values with tropic level of $0-2 \%$ o (Bocherens and Drucker 2003). Values for $\delta^{15} \mathrm{~N}$ tend to be higher in aquatic ecosystems due to the longer length of food chains (Schoeninger et al. 1983). Therefore, although $\delta^{13} \mathrm{C}$ values for marine and $\mathrm{C}_{4}$ consumers can overlap, $\delta^{15} \mathrm{~N}$ values are usually able to distinguish predominantly marine from terrestrial $\mathrm{C}_{4}$ feeders. The Mediterranean is particularly problematic in this regard because $\delta^{15} \mathrm{~N}$ values for marine and terrestrial resources are often similar (Craig et al. 2013). As a result, the identification of consumption of marine foods, as opposed to indirect consumption of $\mathrm{C}_{4}$ crops via $\mathrm{C}_{4}$-fed terrestrial animal protein (with corresponding higher $\delta^{15} \mathrm{~N}$ values), is not always straightforward using bulk isotope analysis due to the problem of equifinality when analysing consumer isotope values (Alexander et al. 2015). 


\section{Materials}

\section{Human populations}

Human bone from 67 individuals was sampled from five sites representing six phases within and outside the medieval city walls (Table 1, Fig. 2), 10 individuals from the Visigothic period, 38 from the Islamic period and 19 from the later Christian period (see Table 1 for dates). Osteological analysis was undertaken by Alexander following established methods to ascertain adult age (ca. 18 years of age and above) based on the development and fusion of bones (Scheuer and Black 2000) and dental eruption and wear (Ubelaker 1989; Brothwell 1981). Sex was determined using standard osteological techniques outlined in Mays and Cox (2000) assessing the morphology of the pelvis and skull and the measurements of bones to support morphological examination.

Individuals were identified as Christian or Muslim from their distinctive burial rites. In general, Christians were buried supine, orientated E-W with their heads to the west, while the Muslims were buried on their right-side orientated SW-NE with their face towards Mecca (Lozoya et al. 2006). Unfortunately, no mozarab or later mudéjar (Muslims under Christian rule) burials were available for analysis. It should also be noted that a Jewish community was present in Valencia throughout the periods examined here, but as no Jewish burials have been analysed, there will be no discussion of this population in this paper.

Both Visigothic and selected Muslim burials were sampled from excavations in the Plaza de la Almoina, the political and religious nucleus of Valencia from the Roman period onwards. Given that this was the area of the Cathedral and Bishop's residence in the sixth and seventh centuries, the
Visigothic burials sampled here have been interpreted as members of the social elite (Martin and Ribera 2006). Burials were sampled from two phases of interments representing both individual and multiple graves (Table 1). The main mosque, originally located here next to the Islamic palace (alcázar), was later converted into the present cathedral. The palace has an adjoining Islamic cemetery (known today as La Rauda) that was situated within the city walls, unlike other cemeteries of the period (Pascual 1989, p. 406; Ribera 2006, p. 82). Historical sources identify this cemetery as the high-status burial ground for the Taifa kingdom (Pascual and Serrano 1996). Samples taken here allow any associations between diet and status within the Islamic population of Valencia to be explored.

Further, burials of the eleventh-thirteenth-century derive from the large cemetery of Bab al-Hanax, and a smaller cemetery uncovered in Carrer Sagunt. The latter is likely to be related to a small extramural suburb and allows comparison between populations of different quarters of the city. Three Muslim burials were also sampled from a group of interments in Carrer Pintor Sorolla. These burials lay within the Islamic city walls and given that this is a practice that was prohibited under normal circumstances, it seems likely that these particular people were interred during the Christian siege of 1238 .

Christian burials were sampled from two early parishes. San Andrés was one of the first parishes created after the Christians took control of the city and was one of the wealthiest during the thirteenth century (Burns 1967, p. 97; García and Ruiz 1997, p. 5). The burial ground excavated near Carrer Sant Vicent was part of a complex of a church, monastery and hospital that was established in the thirteenth century by royal patronage near the shrine dedicated to St Vincent. The monastic group that attended and administered the complex was

Table 1 Details of the human material sampled from medieval Valencia from all sites

\begin{tabular}{|c|c|c|c|c|}
\hline Site & $\begin{array}{l}\text { Date (centuries) } \\
\text { and period }\end{array}$ & $\begin{array}{l}\text { No. of } \\
\text { samples }\end{array}$ & Comments & Reference(s) \\
\hline Plaza de la Almoina & Late 5 th-7th Visigothic & 10 & $\begin{array}{l}\text { Christian rite, early individual interments unfurnished } \\
\text { (5th-6th C), later multiple interments with grave } \\
\text { ornaments (6th-7th C). Potentially high status }\end{array}$ & $\begin{array}{l}\text { Albiach et al. 1998; } \\
\text { Álvarez and Ribera } 2002\end{array}$ \\
\hline $\begin{array}{l}\text { Plaza de la Almoina/La } \\
\text { Rauda }\end{array}$ & 11th-13th Islamic & 7 & $\begin{array}{l}\text { Islamic rite, high status, graves were unfurnished, } \\
\text { lined with mortar with evidence of gold weave } \\
\text { in three graves }\end{array}$ & $\begin{array}{l}\text { Pascual and Ribera 1990; } \\
\text { Pascual and } \\
\text { Serrano } 1996\end{array}$ \\
\hline $\begin{array}{l}\text { Carrer de Dalt 48-58/Bab } \\
\text { al-Hanax }\end{array}$ & 11th-13th Islamic & 21 & Islamic rite, located between two main city gates & Serrano 1997 \\
\hline Carrer Sagunt & 11th-13th Islamic & 7 & $\begin{array}{l}\text { Islamic rite. Cemetery may be related to the small } \\
\text { extramural suburb of la Alcudia }\end{array}$ & Herreros 1999 \\
\hline Carrer Pintor Sorolla & 13th Islamic & 3 & $\begin{array}{l}\text { Islamic rite, buried within the city walls, potentially } \\
\text { related to the Christian siege in AD } 1248\end{array}$ & García and Ruiz 1997 \\
\hline $\begin{array}{l}\text { San Andrés/Carrer } \\
\text { Pintor Sorolla }\end{array}$ & 14th-15th Christian & 4 & $\begin{array}{l}\text { Associated with a wealthy parish established early } \\
\text { in the Christian medieval period }\end{array}$ & García and Ruiz 1997 \\
\hline $\begin{array}{l}\text { Sant Vicent/Carrer } \\
\text { Sant Vicent }\end{array}$ & 14th-15th Christian & 15 & $\begin{array}{l}\text { Associated with a church, monastery and hospital } \\
\text { of royal foundation }\end{array}$ & Ortega and Gálego 2004 \\
\hline
\end{tabular}




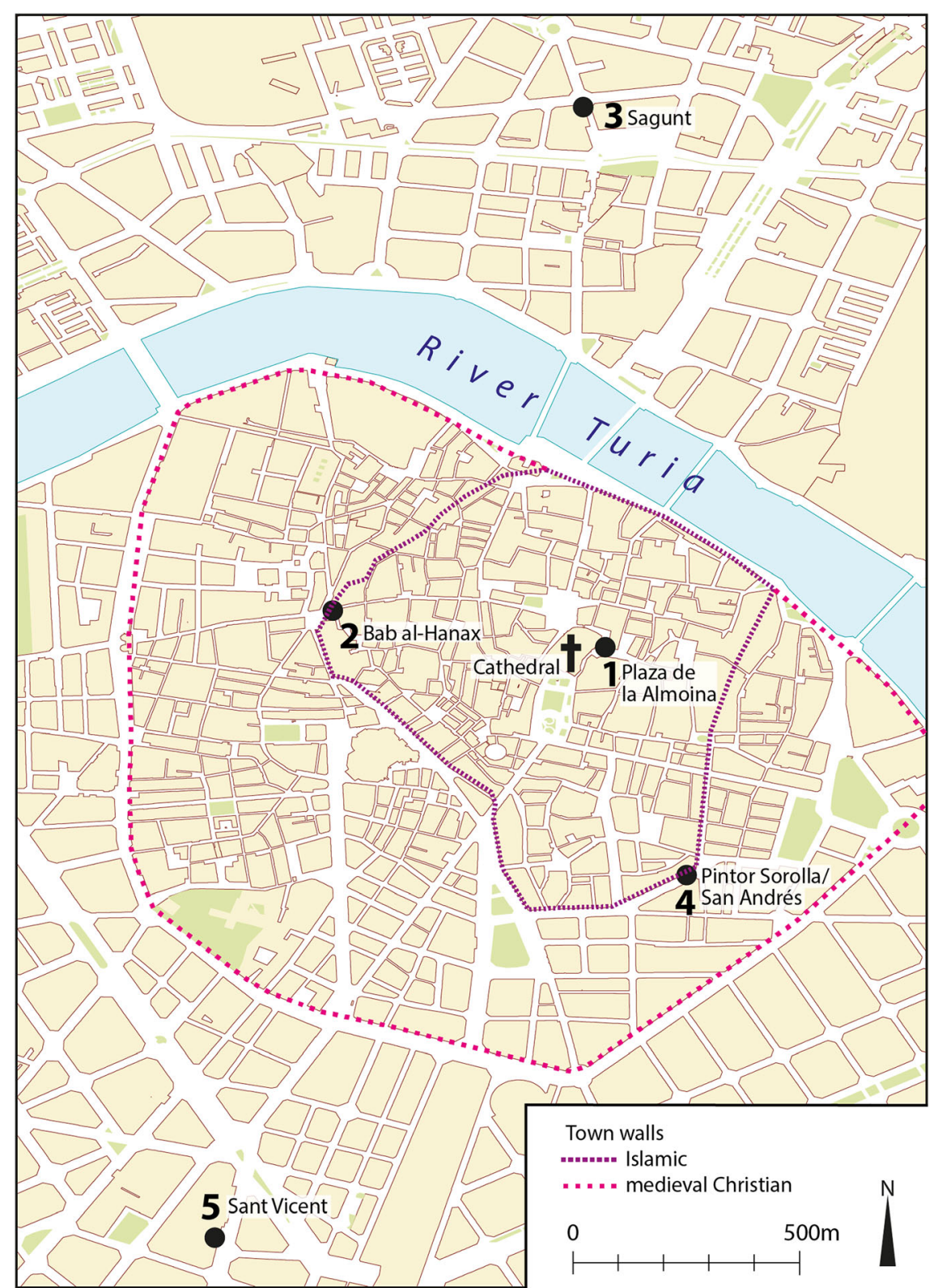

Fig. 2 Map of the modern centre of Valencia with the location of sites sampled. Drawing by A. Gutiérrez after CartoCiudad 2006-2017 CC-BY-4.0 scne.es

chosen by the king and underwent several changes including monks from the monastery of San Victorián, Mercedarians, followed by Cistercians (Burns 1967, pp. 283 and 294). The monastery served as a retirement home for civil servants, families or old soldiers, while the hospital included a hostel for the poor and infirmaries for the sick (Burns 1967, p. 285-286).

\section{Faunal remains}

The animal remains analysed in this study come from wellstratified refuse deposits in the Plaza de la Almoina $(n=42)$. Samples were taken from a selection of contexts dating to the Visigothic (sixth-eighth century), Islamic (eleventh- thirteenth century) and Christian (thirteenth-sixteenth century) periods excavated between 1997 and 2001. Previously published marine fish $\delta^{13} \mathrm{C}$ and $\delta^{15} \mathrm{~N}$ values from other medieval sites in eastern Spain, Albarracín, (Teruel) and Gandía (Valencia) (Alexander et al. 2015) were also included.

\section{Methods}

All human samples derived from adult ( $>18$ years) individuals (based on osteological analysis). Bone (200-500 mg) was preferentially sampled from ribs or cortical bones when ribs were unavailable. Cortical bone was chosen from animal 
specimens (300-500 mg), ensuring that only one sample was taken from one individual in each context. Collagen was isolated from bone following a modified Longin (1971) method (Brown et al. 1988) as described in Alexander et al. (2015).

Collagen $(0.5 \mathrm{mg})$ was analysed in duplicate EA/IRMS with a Delta XP (Thermo-Finnigan $®$, Bremen, Germany) mass spectrometer interfaced with a Costech ESC 4010 elemental analyser at the Alaska Stable Isotope facility (University of Alaska Fairbanks's Water and Environmental Research Centre; WERC) for humans or coupled with a Flash EA 2112 at the Department of Human Evolution, Max Planck Institute for Evolutionary Anthropology (MPI-EVA, Leipzig, Germany), for animals. Stable isotope ratios were reported as $\delta$ values expressed as per mille (\%o) deviation from the international standards VPDB (carbon) and AIR (nitrogen) following the equation ( $\left.\delta=\left(R_{\text {sample }}-R_{\text {standard }}\right) \quad R_{\text {standard }}\right)$ (Coplen 2011). For both laboratories, analytical error (calculated from repeated measurements of each sample and an in-house laboratory gelatine control from multiple extracts) was $<0.2 \%$ $(1 \sigma)$ for both $\delta^{13} \mathrm{C}$ and $\delta^{15} \mathrm{~N}$. Collagen samples were exchanged between laboratories to ensure instrument consistency and as outlined in Alexander et al. (2015), a slight difference $(0.6 \pm 0.2 \%, 1 \sigma)$ was detected between $\delta^{13} \mathrm{C}$ values at each laboratory and though is at the threshold of the minimum meaningful difference (MMD, 0.6\%o) between laboratories suggested by Pestle et al. (2014), it is not at the magnitude of dietary interpretation (typically 1\%; Sealy et al. 2014).

Statistical tests were performed using PAleontological STatistics software (PAST 3.08; Hammer et al. 2001). The non-parametric Mann-Whitney $U$ and Kolmogorov-Smirnov tests were employed, with Kruskal-Wallis tests used to assess overall variability between the three groups.

\section{Results and data interpretation}

The results are presented here alongside an initial interpretation of human diet and animal management within and between periods. The later discussion and synthesis is focused on a diachronic comparison and the wider implications of the results in terms of economy and diet under changing sociopolitical rule.

\section{Sample preservation}

Sufficient collagen ( $>1 \%$ yield) was found to be preserved in all but two samples $(11,025$ and VCP2, Tables 2 and 3 respectively); however, all samples met published collagen quality criteria (DeNiro 1985; van Klinken 1999) and as ultrafiltration can reduce collagen yields (by up to 50\%; Jørkov et al. 2007), compared to unfiltered samples, the data from the two samples with low yield were retained.

\section{All periods}

Human values for all periods $(n=67)$ range from -19.8 to $14.2 \%$ (range of $5.6 \%$ ) in $\delta^{13} \mathrm{C}$ with a mean of $-18.0 \pm 1.1 \%$ o $(1 \sigma)$ and from 8.0 to $17.1 \%$ (range of $9.1 \% \circ$ ) in $\delta^{15} \mathrm{~N}$ with a mean of $11.3 \pm 1.5 \%$ o $(1 \sigma)$. Contemporaneous animals $(n=$ 42) range from -22.3 to $-10 \%$ (range of $12.3 \%$ ) in $\delta^{13} \mathrm{C}$ with a mean of $-19.1 \pm 1.9 \%$ o $(1 \sigma)$ and from 2.5 to $11.5 \%$ o (range of $9 \%$ o) in $\delta^{15} \mathrm{~N}$ with a mean of $6.6 \pm 2.3 \%$ o $(1 \sigma)$. The human and animal stable isotope data for all periods are presented in Tables 2 and 3 respectively and plotted together in Fig. 3; summary statistics for humans and animals in each period are listed in Tables 4 and 5 respectively. Within the Christian period dataset, there is an extreme human outlier, VSVC3622, with a $\delta^{15} \mathrm{~N}$ value (17.1\%o) that is more than three standard deviations (3.3) from the population mean. VSVC3622 was therefore omitted from any statistical comparisons as this individual is considered to be unrepresentative of the local population.

In general, herbivores (cattle, sheep/goat) in all periods tend to have lower $\delta^{13} \mathrm{C}$ and $\delta^{15} \mathrm{~N}$ values than omnivores (chicken, dog, pig) (Table 5). This breadth in values for all species is indicative of a variety of geographic and environmental origins and long-term feeding strategies and must reflect the wide catchment of resources the city was drawing upon, including the possibility of the presence of non-local animals imported from further afield. No one region supplied all the city's needs.

Low $\delta^{13} \mathrm{C}$ values for the majority of domestic animals indicate that $\mathrm{C}_{3}$ plants were the main resource throughout the medieval period and the diets of sheep/goat, the most popular source of meat throughout this time period, are consistently $\mathrm{C}_{3}$-based. Higher $\delta^{13} \mathrm{C}$ values indicative of $\mathrm{C}_{4}$ consumption, however, are seen among cattle, chickens and pigs and a dog (Table 5), indicating some presence of $\mathrm{C}_{4}$ resources in animal diets. In the Islamic and Christian periods, the highest $\delta^{15} \mathrm{~N}$ values for herbivores overlap with humans, a relatively uncommon observation among published medieval faunal data. Given that an effort was made to sample animals older than weaning age, an enrichment of the plant baseline is the most probable explanation here. There is a complex combination of environmental (aridity, salinity) and anthropogenic influences (e.g. manuring) on $\delta^{15} \mathrm{~N}$ in food webs (Heaton 1987; Bogaard et al. 2007). Manuring was widely practiced and, even in the recent past, corrales or bordas (dedicated enclosures for the stabling and foddering of animals) were important for the production of manure to fertilise meadows and hillside terraces (Christie et al. 2004, p. 109; Montserrat and Fillat 1990 , p. 58$). \delta^{15} \mathrm{~N}$ increases may also be attributed to herbivores grazing close to urban settlements in the vicinity of accumulations of human and animal nitrogenous waste (Vassberg 1974; Butzer 1988; Hedges et al. 2005; Triantaphyllou et al. 2008). Grazing of coastal areas and salt 
marshes is an additional factor to be considered (Britton et al. 2008). To the south of Valencia, the Albufera is an extensive wetland with salt marshes around a lagoon (Fig. 1) used as pasture for sheep and cattle (Momblanch 2003; Torró 2012a, b). Aridity may also play a part; some parts of the Valencian region today are dry and semi-arid bioclimatic contexts, with a mean annual rainfall ranging from 500 to less than $300 \mathrm{~mm} /$ year (Hidalgo et al. 2003), particularly areas to the south. Environmental evidence indicates that the Mediterranean region of the Iberian Peninsula experienced particularly dry conditions during the Medieval Warm Period (9001300 AD) (Moreno et al. 2012).

Values for $\delta^{13} \mathrm{C}$ and $\delta^{15} \mathrm{~N}$ for humans indicate that a $\mathrm{C}_{3}$ terrestrial diet predominated in all periods under study. The Islamic data in particular, however, stand apart in demonstrating a variable pattern of $\delta^{13} \mathrm{C}$ values, and a tendency towards elevated $\delta^{15} \mathrm{~N}$ values in comparison to the other periods. A Kruskal-Wallis test comparing sites medians by period for humans indicates there is no difference for $\delta^{13} \mathrm{C}(\mathrm{H}(2): 3.373$, $p=0.184)$ or $\delta^{15} \mathrm{~N}(\mathrm{H}(2): 5.922, p=0.051)$. KolmogorovSmirnov tests for the distribution of isotopic values between sites, however, indicate that there is a significant difference in the distributions of values between $\delta^{13} \mathrm{C}$ and $\delta^{15} \mathrm{~N}$ values for the Islamic period compared to both the Visigothic and Christian periods (Table S1). Examination of patterning in human data between periods needs to take into account potential shifts in the animal baseline, indicative of the environment and husbandry in each period. To that end, herbivores and humans from all periods are plotted together for comparison in Fig. 4. Offsets between humans and herbivores remain similar through all three periods (Table 6) indicating that the shift to $\mathrm{C}_{4}$ plants in particular is broadly reflected in both animals and humans. The dietary shift exhibited in the Islamic period is therefore indicative of an economic shift towards the use of $\mathrm{C}_{4}$ crops in both in human and animal diets rather than solely a change in human food choice. There was no difference between the sexes identified in the isotopic data from any period. The results from each period in Valencia are discussed further below including comparison with other published studies to consider whether Valencia is typical of dietary trends seen elsewhere at similar periods. Figure 5 compares the diet in Visigothic, Islamic and Christian Valencia with other published sites in eastern and southern Spain and the Balearic Islands, areas with similar climates and socio-cultural history.

\section{Visigothic period}

All animals from this period possess a $\mathrm{C}_{3}$-based diet bar one $\operatorname{dog}$ (VVD1, Fig. 3, Tables 3 and 5). This dog possesses a $\delta^{13} \mathrm{C}$ value of $-16.4 \%$, which, combined with a relatively low $\delta^{15} \mathrm{~N}$ value $\left(9 \%\right.$ ) most probably reflects an input of $\mathrm{C}_{4}$-based terrestrial protein in the diet. This is puzzling because dogs are often used as a proxy for human diet (see Guiry 2012), but none of the humans sampled from this period have isotopic values indicative of $\mathrm{C}_{4}$ consumption. Only a small number of humans have been analysed from this period, however, and given that these individuals have been identified as the social elite, they may not reflect the popular diet of the time. Dogs may also have not been fed the 'best' foods from the table. Analyses of further humans and animals from this period are needed to investigate this more thoroughly.

While the results for humans in the Visigothic period are more tightly clustered than later periods (Fig. 3), the two phases of burial fall into two distinct groups (Fig. 6). Burials of the later sixth and seventh centuries are slightly enriched in ${ }^{13} \mathrm{C}$ and ${ }^{15} \mathrm{~N}$ and this is statistically significant for $\delta^{13} \mathrm{C}$ values (Mann-Whitney $U=2.5, p=0.032$ ), although not for $\delta^{15} \mathrm{~N}$ values (Mann-Whitney $U=22, p=0.056$ ). While the sample is small, the significant difference in $\delta^{13} \mathrm{C}$ values is of interest when related to burial practice among these individuals. The earlier burials follow the preceding Hispano-Roman burial tradition with single interments, an absence of grave goods and tiles covering the grave. The later burials, on the other hand, tend to be multiple interments with artefacts (amber pendants, coins and silver objects) and walled tombs, possibly representing family mausolea (Ribera 2008). These changes also correlate with morphological differences observed between the skeletons buried in these two phases: individuals of the later phase are of higher stature and greater robusticity (Martin and Ribera 2006). These findings may reflect an increasing Germanic influence in this quarter of the city and it is recorded, for example, that there was an Arian bishop in the city in AD 589 (Martin and Ribera 2006; Ribera 2008). The isotopic patterning seen here could therefore be a reflection of shifting dietary practice in line with a change in population, although the limited sample size prevents further interpretation.

More broadly, the Valencian Visigothic data are comparable to sixth- and seventh-century 'Late Roman' individuals from Tossal de les Basses in Alicante (SalazarGarcía et al. 2016) and fourth-seventh-century Late Antique/Early Byzantine individuals from Ibiza (Fuller et al. 2010) in Fig. 5. Of these two, the values for Valencia are remarkably similar to Tossal de les Basses, indicating that diets in these two places were comparable, with $\mathrm{C}_{3}$-based diets for humans at both sites.

\section{Islamic period}

Among the animal data from the Islamic period, both cattle and chickens stand out for their wide range in $\delta^{13} \mathrm{C}$ values (4.3\%o and $7.9 \%$ respectively, Table 5) indicative of diverse feeding strategies in both species. Some individuals possess low $\delta^{13} \mathrm{C}$ values indicative of $\mathrm{C}_{3}$ consumption whereas others have values reflecting a significant proportion of $\mathrm{C}_{4}$ plants in their diets, including one chicken (VMGa2) with an extreme 
Table 2 Stable carbon and nitrogen isotope data for human bone collagen from all sites ( $\mathrm{F}=$ female, $\mathrm{M}=$ male)

\begin{tabular}{|c|c|c|c|c|c|c|c|c|c|c|}
\hline Period & Site & Skeleton & Element & Sex & $\delta^{13} \mathrm{C}_{\mathrm{VPDB}}(\% \circ)$ & $\delta^{15} \mathrm{~N}_{\mathrm{AIR}}(\% o)$ & $\mathrm{C}(\%)$ & $\mathrm{N}(\%)$ & $\mathrm{C} / \mathrm{N}$ & $\% \mathrm{Col}$ \\
\hline Visigothic & Almoina 8 & $10602^{\mathrm{b}}$ & Rib & $? \mathrm{~F}$ & -18.5 & 11.3 & 43.0 & 15.5 & 3.2 & 10.9 \\
\hline \multirow{9}{*}{$\begin{array}{l}\text { Christian } \\
(5 \text { th-7th C) }\end{array}$} & Almoina 8 & 10572 & Femur & $\mathrm{F}$ & -18.5 & 10.7 & 42.7 & 15.5 & 3.2 & 6.3 \\
\hline & Almoina 8 & $10603^{\mathrm{b}}$ & Femur & $? \mathrm{M}$ & -18.6 & 11.4 & 41.4 & 13.8 & 3.5 & 1.1 \\
\hline & Almoina 8 & 10562 & Rib & $? \mathrm{M}$ & -18.6 & 11.3 & 42.6 & 15.3 & 3.2 & 1.4 \\
\hline & Almoina 11 & 10940 & Rib & $? \mathrm{~F}$ & -18.7 & 10.5 & 43.1 & 15.6 & 3.2 & 11.2 \\
\hline & Almoina 11 & 10835 & Rib & $\mathrm{F}$ & -18.6 & 9.5 & 40.2 & 14.6 & 3.2 & 1.5 \\
\hline & Almoina 11 & $7602^{\mathrm{b}}$ & Rib & $\mathrm{F}$ & -18.0 & 11.3 & 43.0 & 15.7 & 3.2 & 10.3 \\
\hline & Almoina 11 & 11,025 & Rib & M & -18.7 & 10.6 & 33.0 & 11.8 & 3.3 & $0.8^{\mathrm{a}}$ \\
\hline & Almoina 11 & $10689^{\mathrm{b}}$ & Rib & M & -18.1 & 10.9 & 42.3 & 15.2 & 3.2 & 4.2 \\
\hline & Almoina 11 & $10694^{\mathrm{b}}$ & Rib & M & -18.0 & 10.8 & 43.6 & 16.0 & 3.2 & 1.3 \\
\hline Islamic & Almoina 1 & 1281 & Rib & $?$ & -18.1 & 10.7 & 45.5 & 15.8 & 3.4 & 6.5 \\
\hline \multirow[t]{37}{*}{ (11th-13th C) } & Almoina 1 & 1356 & Rib & $?$ & -16.3 & 16.6 & 45.8 & 17.2 & 3.1 & 9.6 \\
\hline & Almoina 1 & 1428 & Rib & $?$ & -17.8 & 11.6 & 46.0 & 16.9 & 3.2 & 8.3 \\
\hline & Almoina 1 & 1363 & Rib & $\mathrm{F}$ & -17.0 & 13.8 & 46.1 & 16.9 & 3.2 & 4.7 \\
\hline & Almoina 1 & 1295 & Rib & $\mathrm{F}$ & -18.9 & 11.4 & 46.8 & 16.6 & 3.3 & 6.7 \\
\hline & Almoina 1 & 1344 & Femur & M & -17.3 & 14.2 & 46.0 & 16.6 & 3.2 & 2.1 \\
\hline & Almoina 1 & 1095 & Rib & M & -15.8 & 12.2 & 51.2 & 18.3 & 3.3 & 2.0 \\
\hline & Carrer de Dalt 48-58 & 1434 & Femur & $?$ & -19.8 & 9.7 & 42.8 & 15.2 & 3.3 & 1.1 \\
\hline & Carrer de Dalt 48-58 & 1568 & Femur & $? \mathrm{~F}$ & -18.1 & 11.5 & 36.7 & 13.1 & 3.3 & 1.0 \\
\hline & Carrer de Dalt 48-58 & 2375 & Femur & $? \mathrm{~F}$ & -16.6 & 12.1 & 45.4 & 16.4 & 3.2 & 4.3 \\
\hline & Carrer de Dalt 48-58 & 1354 & Rib & ?F & -17.7 & 10.3 & 49.7 & 17.8 & 3.3 & 3.9 \\
\hline & Carrer de Dalt 48-58 & 1632 & Rib & $\mathrm{F}$ & -18.8 & 10.1 & 45.6 & 16.3 & 3.3 & 3.5 \\
\hline & Carrer de Dalt 48-58 & 2094 & Rib & $\mathrm{F}$ & -19.3 & 11.0 & 46.7 & 17.3 & 3.2 & 1.9 \\
\hline & Carrer de Dalt 48-58 & 1941 & Femur & $\mathrm{F}$ & -19.2 & 10.8 & 47.4 & 15.3 & 3.6 & 2.2 \\
\hline & Carrer de Dalt 48-58 & 2036 & Rib & $\mathrm{F}$ & -18.8 & 10.3 & 48.3 & 17.1 & 3.3 & 2.0 \\
\hline & Carrer de Dalt 48-58 & 1419 & Femur & $\mathrm{F}$ & -19.2 & 10.8 & 48.4 & 16.8 & 3.4 & 2.1 \\
\hline & Carrer de Dalt $48-58$ & 2549 & Rib & $\mathrm{F}$ & -18.4 & 10.5 & 49.4 & 18.8 & 3.1 & 8.0 \\
\hline & Carrer de Dalt 48-58 & 2544 & Rib & $\mathrm{F}$ & -15.8 & 11.5 & 49.4 & 17.4 & 3.3 & 1.6 \\
\hline & Carrer de Dalt 48-58 & 1565 & Femur & $? \mathrm{M}$ & -17.3 & 12.2 & 40.7 & 14.8 & 3.2 & 1.5 \\
\hline & Carrer de Dalt 48-58 & 1330 & Femur & $? \mathrm{M}$ & -18.8 & 10.5 & 42.1 & 14.8 & 3.3 & 2.2 \\
\hline & Carrer de Dalt 48-58 & 2369 & Femur & $? \mathrm{M}$ & -17.6 & 10.6 & 43.7 & 16.5 & 3.1 & 3.2 \\
\hline & Carrer de Dalt 48-58 & 2292 & Rib & $? \mathrm{M}$ & -18.6 & 9.9 & 46.0 & 17.3 & 3.1 & 9.5 \\
\hline & Carrer de Dalt 48-58 & 2193 & Femur & M & -18.3 & 9.3 & 44.0 & 16.4 & 3.1 & 2.8 \\
\hline & Carrer de Dalt 48-58 & 1945 & Femur & M & -19.1 & 10.3 & 45.4 & 16.2 & 3.3 & 2.3 \\
\hline & Carrer de Dalt 48-58 & 1366 & Femur & M & -19.0 & 11.2 & 45.5 & 15.8 & 3.3 & 1.3 \\
\hline & Carrer de Dalt 48-58 & 2011 & Femur & M & -18.5 & 11.0 & 47.0 & 17.8 & 3.1 & 2.0 \\
\hline & Carrer de Dalt 48-58 & 2536 & Rib & M & -18.8 & 11.4 & 48.6 & 18.3 & 3.1 & 8.5 \\
\hline & Carrer de Dalt 48-58 & 2132 & Rib & M & -18.9 & 10.7 & 49.1 & 16.6 & 3.5 & 2.9 \\
\hline & Carrer Pintor Sorolla & 1809 & Rib & $? \mathrm{~F}$ & -16.3 & 11.8 & 39.7 & 14.0 & 3.3 & 2.8 \\
\hline & Carrer Pintor Sorolla & 1807 & Rib & $\mathrm{F}$ & -15.2 & 12.3 & 44.0 & 15.9 & 3.2 & 4.2 \\
\hline & Carrer Pintor Sorolla & 1805 & Rib & M & -16.6 & 12.0 & 46.9 & 16.7 & 3.3 & 3.3 \\
\hline & Carrer Sagunt & 1217 & Rib & $? \mathrm{M}$ & -16.7 & 12.0 & 42.4 & 15.3 & 3.2 & 6.4 \\
\hline & Carrer Sagunt & 1586 & Rib & $? \mathrm{M}$ & -16.9 & 12.0 & 44.4 & 15.4 & 3.4 & 3.6 \\
\hline & Carrer Sagunt & 1117 & Rib & $\mathrm{F}$ & -15.8 & 11.7 & 41.7 & 14.9 & 3.3 & 12.3 \\
\hline & Carrer Sagunt & 1192 & Rib & $\mathrm{F}$ & -17.6 & 14.5 & 44.4 & 15.7 & 3.3 & 4.7 \\
\hline & Carrer Sagunt & 1399 & Rib & $\mathrm{F}$ & -17.1 & 13.4 & 48.0 & 17.4 & 3.2 & 14.5 \\
\hline & Carrer Sagunt & 1290 & Humerus & M & -17.9 & 12.2 & 41.5 & 14.3 & 3.4 & 9.1 \\
\hline & Carrer Sagunt & 1331 & Rib & M & -14.2 & 11.0 & 48.2 & 17.1 & 3.3 & 2.9 \\
\hline
\end{tabular}


Table 2 (continued)

\begin{tabular}{|c|c|c|c|c|c|c|c|c|c|c|}
\hline Period & Site & Skeleton & Element & Sex & $\delta^{13} \mathrm{C}_{\mathrm{VPDB}}(\% \circ)$ & $\delta^{15} \mathrm{~N}_{\mathrm{AIR}}(\% o)$ & $\mathrm{C}(\%)$ & $\mathrm{N}(\%)$ & $\mathrm{C} / \mathrm{N}$ & $\% \mathrm{Col}$. \\
\hline \multirow{19}{*}{$\begin{array}{l}\text { Christian } \\
\text { (14th-15th C) }\end{array}$} & San Andrés IPSOS47 & 1585 & Rib & $\mathrm{F}$ & -18.2 & 11.2 & 34.6 & 11.6 & 3.5 & 2.6 \\
\hline & San Andrés IPSOS47 & 1466 & Rib & $\mathrm{F}$ & -18.1 & 11.7 & 44.7 & 16.4 & 3.2 & 8.1 \\
\hline & San Andrés IPSOS47 & 1549 & Rib & $\mathrm{F}$ & -18.1 & 11.3 & 48.1 & 17.4 & 3.2 & 4.6 \\
\hline & San Andrés IPSOS47 & 1649 & Rib & $\mathrm{F}$ & -18.4 & 10.5 & 49.3 & 17.1 & 3.4 & 2.3 \\
\hline & Carrer Sant Vicent 134 & 3048 & Rib & $?$ & -18.5 & 11.3 & 46.4 & 16.9 & 3.2 & 11.1 \\
\hline & Carrer Sant Vicent 134 & 3277 & Rib & ?F & -19.3 & 9.3 & 40.5 & 14.4 & 3.3 & 4.3 \\
\hline & Carrer Sant Vicent 134 & 3274 & Rib & $? \mathrm{~F}$ & -17.3 & 11.6 & 49.1 & 17.8 & 3.2 & 10.9 \\
\hline & Carrer Sant Vicent 134 & 3054 & Rib & $\mathrm{F}$ & -18.3 & 10.3 & 49.0 & 17.9 & 3.2 & 12.7 \\
\hline & Carrer Sant Vicent 134 & 3280 & Rib & $\mathrm{F}$ & -18.7 & 8.4 & 49.5 & 17.1 & 3.4 & 6.0 \\
\hline & Carrer Sant Vicent 134 & 3283 & Rib & $? \mathrm{M}$ & -18.8 & 8.0 & 45.4 & 16.0 & 3.3 & 3.0 \\
\hline & Carrer Sant Vicent 134 & 3325 & Rib & $? \mathrm{M}$ & -18.4 & 11.6 & 45.7 & 16.2 & 3.3 & 5.0 \\
\hline & Carrer Sant Vicent 134 & 3289 & Rib & $? \mathrm{M}$ & -18.9 & 10.1 & 46.5 & 16.7 & 3.3 & 4.0 \\
\hline & Carrer Sant Vicent 134 & 3070 & Rib & M & -18.5 & 11.3 & 38.1 & 13.1 & 3.4 & 3.7 \\
\hline & Carrer Sant Vicent 134 & 3051 & Rib & M & -18.8 & 11.1 & 40.7 & 14.2 & 3.3 & 7.7 \\
\hline & Carrer Sant Vicent 134 & 3244 & Rib & M & -16.8 & 10.6 & 44.3 & 15.5 & 3.3 & 2.8 \\
\hline & Carrer Sant Vicent 134 & 3334 & Rib & M & -18.1 & 11.3 & 45.1 & 16.4 & 3.2 & 9.1 \\
\hline & Carrer Sant Vicent 134 & 3677 & Rib & M & -19.1 & 9.1 & 47.9 & 17.2 & 3.2 & 5.0 \\
\hline & Carrer Sant Vicent 134 & 3220 & Rib & M & -18.5 & 10.9 & 48.3 & 17.9 & 3.2 & 10.1 \\
\hline & Carrer Sant Vicent 134 & 3622 & Rib & M & -18.7 & 17.1 & 41.6 & 13.8 & 3.5 & 5.9 \\
\hline
\end{tabular}

${ }^{\mathrm{a}}$ Yield $<1 \%$ but data retained

${ }^{\mathrm{b}}$ These burials are thought to date to the late 5th-early 6th century

$\delta^{13} \mathrm{C}$ value of $-10 \%$ o. The same $\mathrm{C}_{3} / \mathrm{C}_{4}$ patterning among cattle was found in the rural Muslim settlement of Gandía in a later period (Alexander et al. 2015). In line with the evidence presented here, species of millet are mentioned among the grains used to fatten both cattle and chickens by the agronomist Ibn al-Awwam in his twelfth-century Treatise on Agriculture (Ibn al-Awwam 1802). In north-west Spain, ethnographic evidence demonstrates that millet is still traditionally used for foddering animals, particularly stabled cattle and chickens (MorenoLarrazabal et al. 2015).

Human data from Islamic Valencia exhibit a strikingly wide range in both $\delta^{13} \mathrm{C}(5.5 \%)$ and $\delta^{15} \mathrm{~N}(7.0 \%$, Table 4). When the isotopic data is plotted (Fig. 3), a core group of individuals show $\delta^{13} \mathrm{C}$ and $\delta^{15} \mathrm{~N}$ values $(-19.0$ to $-18.0 \%$ o and 10 to $12 \%$ respectively) indicative of a predominantly terrestrial, $\mathrm{C}_{3}$-based diet. Isotopic values for the reminder of the sampled individuals suggest the consumption of marine fish and/or $\mathrm{C}_{4}$ protein (directly and/or indirectly). As previously noted, it is difficult to disentangle the consumption of marine fish rather than $\mathrm{C}_{4}$ resources in the Mediterranean environment, although trends are discernible that could indicate the consumption of one over the other. One group of individuals possess increasingly higher $\delta^{13} \mathrm{C}$ values $>-18 \%$ o but relatively constant $\delta^{15} \mathrm{~N}$ values of around $12 \%$, indicating input of $\mathrm{C}_{4}$ resources, whereas other individuals exhibit considerable enrichment in ${ }^{15} \mathrm{~N}\left(\delta^{15} \mathrm{~N}\right.$ values of up to $17 \%$ o) coupled with corresponding higher $\delta^{13} \mathrm{C}$ values $(-18$ to $-16 \%$ o) suggesting marine protein consumption.

This variability is also visible by site (Fig. 7), suggesting that a range of dietary resources was available across the city and between communities. Only the individuals from the Bab al-Hanax cemetery plot in a relatively cohesive group with some individuals tailing out towards higher $\delta^{13} \mathrm{C}$ values. For the most part, this population may represent locals of middling status who subsisted mainly on $\mathrm{C}_{3}$ terrestrial foods.

Burials from Carrer Sagunt, associated with the artisan suburb of la Alcudia outside the city, are especially notable for their extremely variable $\delta^{13} \mathrm{C}$ and $\delta^{15} \mathrm{~N}$ values; these individuals have some of the highest $\delta^{15} \mathrm{~N}$ values exhibited by the population. The three individuals from Carrer Pintor Sorolla, believed to date to the late thirteenth-century siege, all show higher $\delta^{13} \mathrm{C}$ values indicative of $\mathrm{C}_{4}$ protein consumption. High-status burials from La Rauda are again highly variable, with some plotting with the majority in Carrer de Dalt, whereas others possess higher $\delta^{13} \mathrm{C}$ and $\delta^{15} \mathrm{~N}$ values. The latter group may have consumed a greater proportion of marine resources ( $>50 \%$ for individual VRM1356 following Richards et al. 2006); alternatively, these individuals may have originated elsewhere. 
Table 3 Full $\delta^{13} \mathrm{C}$ and $\delta^{15} \mathrm{~N}$ results for medieval animal bone collagen from Valencia. Those marked by a dot $(\bullet$ ) are marine fish (Alexander et al. 2015)

\begin{tabular}{|c|c|c|c|c|c|c|c|c|c|c|}
\hline Sample & S-EVA & Site & Period & Species & $\delta^{13} \mathrm{C}_{\mathrm{VPDB}}(\% \circ)$ & $\delta^{15} \mathrm{~N}_{\mathrm{AIR}}(\% o)$ & $\mathrm{C}(\%)$ & $\mathrm{N}(\%)$ & $\mathrm{C} / \mathrm{N}$ & $\%$ Col. \\
\hline VVC1 & 13616 & Almoina 8 & 6 th-8th & Cow & -20.1 & 3.7 & 42.9 & 15.5 & 3.2 & 3.8 \\
\hline VVC2 & 13576 & Almoina 8 & 6th-8th & Cow & -18.6 & 3.9 & 42.6 & 15.2 & 3.3 & 1.9 \\
\hline VVD1 & 13571 & Almoina 8 & 6 th-8th & Dog & -16.4 & 9.0 & 40.7 & 14.9 & 3.2 & 2.9 \\
\hline VVG1 & 13559 & Almoina 8 & 6 th-8th & Goat & -18.9 & 3.7 & 42.8 & 15.4 & 3.2 & 4.9 \\
\hline VVO1 & 13612 & Almoina 8 & 6 th-8th & Sheep & -20.5 & 6.1 & 43.1 & 15.7 & 3.2 & 3.1 \\
\hline VVO2 & 13569 & Almoina 8 & 6 th-8th & Sheep/goat & -19.4 & 5.7 & 42.6 & 15.6 & 3.2 & 5.7 \\
\hline VVO3 & 13560 & Almoina 8 & 6 th-8th & Sheep & -20.1 & 7.4 & 43.6 & 15.9 & 3.2 & 9.8 \\
\hline VVO4 & 13566 & Almoina 8 & 6th-8th & Sheep & -20.0 & 5.2 & 42.2 & 15.4 & 3.2 & 4.0 \\
\hline VVP1 & 13570 & Almoina 8 & 6 th-8th & Pig & -19.0 & 8.4 & 42.4 & 15.1 & 3.3 & 4.8 \\
\hline VVP2 & 13564 & Almoina 8 & 6 th-8th & Pig & -18.5 & 7.2 & 41.6 & 15.0 & 3.2 & 2.4 \\
\hline VVP3 & 13565 & Almoina 8 & 6th-8th & Pig & -19.4 & 8.5 & 40.1 & 14.5 & 3.2 & 2.6 \\
\hline VVR1 & 13615 & Almoina 8 & 6 th-8th & Rabbit & -22.3 & 3.7 & 44.0 & 15.5 & 3.3 & 5.9 \\
\hline VMC1 & 7895 & Almoina 8 & 10th-13th & Cow & -18.8 & 7.0 & 36.9 & 13.5 & 3.2 & 1.0 \\
\hline VMC2 & 7893 & Almoina 10 & 10 th-13th & Cow & -16.8 & 7.0 & 40.5 & 15.0 & 3.2 & 4.2 \\
\hline VMC3 & 7919 & Almoina 10 & 10th-13th & Cow & -18.4 & 8.5 & 34.2 & 12.6 & 3.2 & 1.4 \\
\hline VMC4 & 7905 & Almoina 10 & 10th-13th & Cow & -20.1 & 2.5 & 42.0 & 15.0 & 3.3 & 2.8 \\
\hline VMC5 & 7918 & Almoina 8 & 10th-13th & Cow & -15.8 & 5.9 & 43.8 & 16.3 & 3.1 & 5.6 \\
\hline VMGa1 & 13607 & Almoina 10 & 10th-13th & Chicken & -17.9 & 11.4 & 43.2 & 15.5 & 3.2 & 12.3 \\
\hline VMGa2 & 13608 & Almoina 10 & 10th-13th & Chicken & -10.0 & 11.5 & 43.4 & 15.6 & 3.3 & 7.8 \\
\hline VMO4 & 7917 & Almoina 8 & 10th-13th & Sheep/goat & -20.4 & 9.7 & 42.2 & 15.3 & 3.2 & 1.7 \\
\hline VMO5 & 7901 & Almoina 8 & 10th-13th & Sheep/goat & -19.7 & 5.5 & 43.8 & 16.0 & 3.2 & 2.0 \\
\hline VMO6 & 7916 & Almoina 10 & 10th-13th & Sheep/goat & -19.4 & 3.8 & 40.1 & 14.9 & 3.1 & 3.5 \\
\hline VMO1 & 7910 & Almoina 10 & 10th-13th & Sheep & -19.3 & 2.8 & 38.3 & 13.9 & 3.2 & 1.0 \\
\hline VMO2 & 7894 & Almoina 8 & 10th-13th & Sheep & -20.3 & 8.0 & 42.2 & 15.6 & 3.2 & 3.9 \\
\hline VMO3 & 7909 & Almoina 10 & 10th-13th & Sheep & -19.0 & 9.6 & 37.7 & 13.8 & 3.2 & 1.3 \\
\hline VMS1 & 7896 & Almoina 8 & 10th-13th & Sheep & -18.9 & 7.1 & 43.9 & 16.1 & 3.2 & 1.0 \\
\hline VMS2 & 7897 & Almoina 10 & 10th-13th & Sheep & -18.6 & 5.3 & 42.6 & 15.5 & 3.2 & 5.6 \\
\hline VMP1 & 7915 & Almoina 8 & 10th-13th & Pig & -19.5 & 7.7 & 41.4 & 15.0 & 3.2 & 1.6 \\
\hline $\mathrm{VCCl}$ & 7914 & Almoina 9-10 & 13th-16th & Cow & -20.6 & 6.0 & 43.1 & 15.8 & 3.2 & 2.2 \\
\hline VCC2 & 7902 & Almoina 8 & 13th-14th & Cow & -19.9 & 9.0 & 44.5 & 16.4 & 3.2 & 3.5 \\
\hline VCO1 & 7920 & Almoina 9-10 & 13 th-16th & Sheep/goat & -20.4 & 4.3 & 44.6 & 16.4 & 3.2 & 3.2 \\
\hline VCO4 & - & Almoina 9-10 & 13th-16th & Sheep/goat & -19.3 & 5.2 & 42.0 & 15.3 & 3.2 & 6.2 \\
\hline VCO2 & 7903 & Almoina 8 & 13th-14th & Sheep & -20.6 & 8.0 & 41.6 & 15.4 & 3.2 & 3.4 \\
\hline VCO3 & 7907 & Almoina 9-10 & 13 th-16th & Sheep/goat & -19.5 & 3.0 & 42.2 & 15.4 & 3.2 & 3.4 \\
\hline VCS1 & 7898 & Almoina 8 & 13th-14th & Sheep & -19.3 & 4.9 & 39.3 & 14.5 & 3.2 & 2.1 \\
\hline VCS2 & 7913 & Almoina 8 & 13th-14th & Sheep & -20.0 & 7.7 & 39.6 & 14.4 & 3.2 & 1.5 \\
\hline VCS3 & 7899 & Almoina 9-10 & 13 th-16th & Sheep & -20.7 & 5.7 & 35.1 & 12.8 & 3.2 & 1.8 \\
\hline VCP1 & 7911 & Almoina 9-10 & 13 th-16th & Pig & -19.6 & 9.6 & 41.4 & 15.1 & 3.2 & 3.0 \\
\hline $\mathrm{VCP} 2$ & 7904 & Almoina 8 & 13th-14th & Pig & -18.3 & 8.8 & 26.2 & 9.5 & 3.2 & $0.4^{\mathrm{a}}$ \\
\hline VCP3 & 7900 & Almoina 9-10 & 13 th-16th & Pig & -19.6 & 8.0 & 40.1 & 14.6 & 3.2 & 1.0 \\
\hline VCP4 & 7906 & Almoina 9-10 & 13 th-16th & Pig & -17.0 & 8.8 & 39.7 & 14.7 & 3.2 & 1.8 \\
\hline VCR1 & 7912 & Almoina 8 & 13th-14th & Rabbit & -21.8 & 4.6 & 25.1 & 8.9 & 3.3 & 1.6 \\
\hline $\mathrm{ABF} 1 \bullet$ & 7889 & Albarracín & 10th-12th & Mugilidae & -10.1 & 8.1 & 44.1 & 16.2 & 3.2 & 3.9 \\
\hline ABF3• & 7890 & Albarracín & 10th-12th & Argyrosomus & -10.8 & 10.4 & 42.7 & 16.3 & 3.0 & 16.2 \\
\hline ABF4• & 7891 & Albarracín & 10 th-12th & Dicentratchus & -11.2 & 12.6 & 42.7 & 16.1 & 3.1 & 4.1 \\
\hline ABF5• & 7888 & Albarracín & 10th-12th & Mugilidae & -9.4 & 9.5 & 45.9 & 16.6 & 3.2 & 3.8 \\
\hline ABF6• & 7892 & Albarracín & 10 th-12th & Dicentratchus & -11.4 & 12.5 & 44.8 & 16.6 & 3.2 & 6.2 \\
\hline GBF1• & 7887 & Gandía & 15 th-16th & Galeorhinuseus & -12.4 & 9.9 & 42.9 & 15.3 & 3.3 & 4.6 \\
\hline
\end{tabular}

${ }^{\mathrm{a}}$ Yield $<1 \%$ but data retained

The presence of non-locals may explain the variation in the population overall. As a successful port, Valencia was at the centre of political, familial, trade and travel links between alAndalus and the Maghreb during the eleventh to thirteenth centuries (Glick 2005, p. 357). The people buried at La Rauda are believed to have been those related either politically or by kinship to the Almoravid and Almohad rulers of Valencia and it is very probable that some of these elites may have originated from areas such as the Almohad capital of Marrakesh on the edge of the Sahara in North Africa (Boone and Benco 1999; Torró 2009b). Written records indicate that both members of the nobility and inhabitants of other cities in the Valencian territory were buried at Bab al-Hanax (Pascual and Serrano 1996, p. 232). There were continuous waves of Berber immigrants from North Africa into alAndalus throughout the Islamic period and their frequency increased from the tenth century onwards (Guichard 2000). Slaves would have also been a major presence in Valencia 
during this period. The presence of, and access to, black slaves in al-Andalus purportedly goes back to the eleventh century and is associated with Islamic penetration of sub-Saharan areas and the arrival of the Almoravid and Almohad dynasties from North Africa (Constable 1996, p. 269). It may be that some of the individuals identified with relatively high $\delta^{15} \mathrm{~N}$
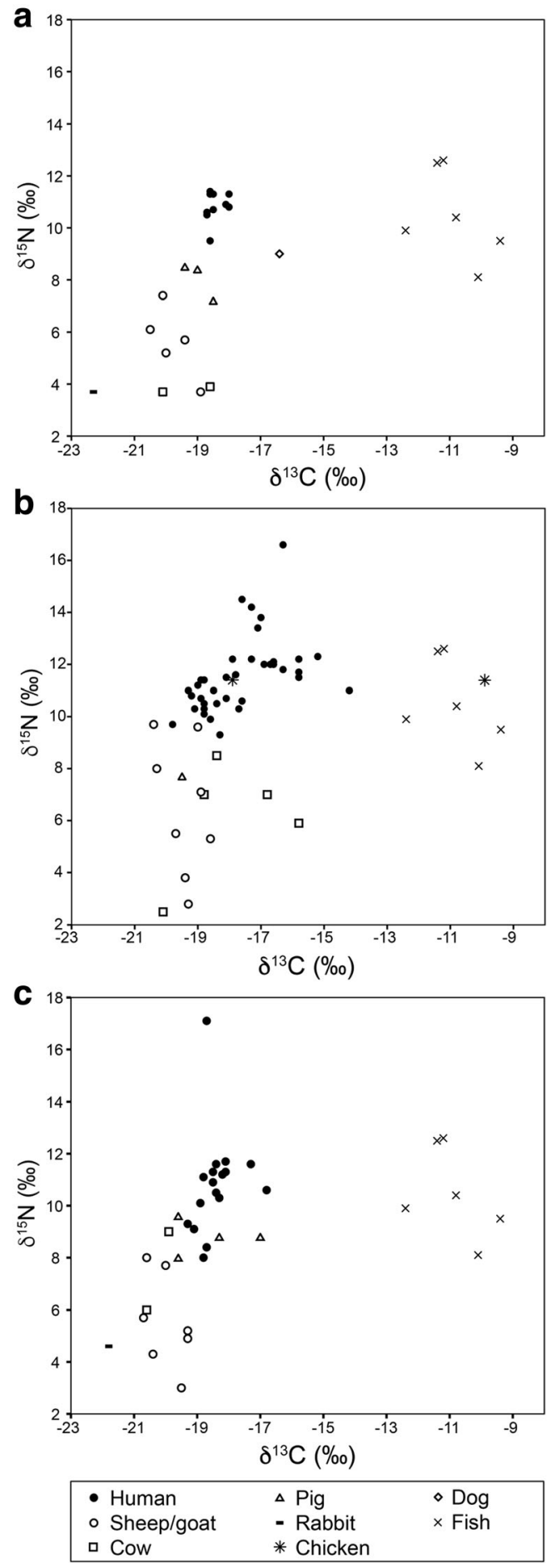

Fig. 3 Stable carbon and nitrogen isotope data for animal and human bone collagen for each period, Visigothic (a), Islamic (b) and Christian (c) and $\delta^{13} \mathrm{C}$ values originated from the Maghreb. Substantial enrichment in ${ }^{15} \mathrm{~N}$ of consumer bone collagen has been reported from arid areas such as Dakheleh Oasis in the Sahara $\left(\delta^{15} \mathrm{~N}\right.$ values from around 15 to $18 \%$, Schwarcz et al. 1999; Dupras and Schwarcz 2001) and $\delta^{13} \mathrm{C}$ values, similar to those exhibited here, have been reported in human collagen samples from archaeological populations from North Africa, for example from Sudanese Nubia (Turner et al. 2007).

In the wider context, this variability in isotopic values, particularly for $\delta^{13} \mathrm{C}$, is also a feature of published isotopic values for Islamic populations in other parts of Spain (Fig. 5). This is often due to the presence of specific outliers increasing the standard deviation of these populations, particularly in those cases with smaller samples, e.g. La Torrecilla, Granada (Jiménez-Brobeil et al. 2016). In the tenth-thirteenthcentury Islamic population from Can Fonoll, Ibiza, there was a wide range of $\delta^{13} \mathrm{C}$ values, but only four individuals had values above $-16 \%$ indicative of significant input of $\mathrm{C}_{4}$ resources and these were therefore interpreted as migrants (Pickard et al. 2017). In Valencia, by contrast, many individuals exhibit increased $\delta^{13} \mathrm{C}$ values and although the presence of migrants is highly likely, individual choice or restriction in diet cannot be ruled out.

Local socioeconomic factors must therefore also be considered, where low status individuals and/or slaves may have relied on $\mathrm{C}_{4}$ grain in particular. On the other hand, individuals with higher $\delta^{13} \mathrm{C}$ values may be local migrants from rural areas where $\mathrm{C}_{4}$ grain was utilised more widely. Isotopic evidence points to a rural-urban divide where later medieval Islamic communities from rural contexts exhibit higher $\delta^{13} \mathrm{C}$ values indicative of $\mathrm{C}_{4}$ signatures (Fig. 5), e.g. La Torrecilla (Jiménez-Brobeil et al. 2016), Benipeixcar (Alexander et al. 2015) and El Raval (Salazar-García et al. 2014).

\section{Christian period}

Animal data for the Christian period indicates a return to a predominantly $\mathrm{C}_{3}$-based diet, although no chickens and only two cows were sampled from contexts dating to this period (Fig. 3, Table 5). Perhaps more samples of these species in particular would reveal further diversity. Data for pigs are most notable among the animal data for this period, demonstrating more enrichment in ${ }^{15} \mathrm{~N}$ in comparison to earlier periods (minimum $\delta^{15} \mathrm{~N}$ value $8 \%$, maximum $\delta^{15} \mathrm{~N}$ value $9 \%$, $n=4$, Table 5). This is perhaps indicative of more intensive husbandry and inclusion of animal protein in the diet of pigs that may signal a renewed importance for animal for the Christian populace. One pig (VCP4, Table 3) is also enriched in ${ }^{13} \mathrm{C}$, with a $\delta^{13} \mathrm{C}$ value of $-17.0 \%$. This suggests the input of a source of ${ }^{13} \mathrm{C}$-enriched carbon in the diet, probably from $\mathrm{C}_{4}$-derived protein rather than marine sources as the pigs have lower $\delta^{15} \mathrm{~N}$ values than the majority of humans (Fig. 3). 
Table 4 Summary stable carbon and nitrogen isotope data for human bone collagen from all sites in each period

\begin{tabular}{|c|c|c|c|c|c|c|c|c|c|}
\hline \multirow[t]{2}{*}{ Period (centuries) } & \multirow[t]{2}{*}{$n$} & \multicolumn{4}{|c|}{$\delta^{13} \mathrm{C}_{\mathrm{VPDB}}(\% o)$} & \multicolumn{4}{|c|}{$\delta^{15} \mathrm{~N}_{\mathrm{AIR}}(\% \circ)$} \\
\hline & & Min & Max & Range & Mean \pm 1 & Min & Max & Range & Mean \pm 1 \\
\hline Visigothic, 5th-7thC & 10 & -18.7 & -18.0 & 0.7 & $-18.4 \pm 0.3$ & 9.5 & 11.4 & 1.9 & $10.8 \pm 0.6$ \\
\hline Islamic, 11th-13thC & 38 & -19.8 & -14.2 & 5.6 & $-17.7 \pm 1.3$ & 9.3 & 16.6 & 7.3 & $11.5 \pm 1.4$ \\
\hline Christian, 14th-15thC & 19 & -19.3 & -16.8 & 2.5 & $-18.4 \pm 0.6$ & 8 & 17.1 & 9.1 & $10.9 \pm 1.9$ \\
\hline
\end{tabular}

Human individuals from the later medieval Christian Valencia (Table 4) display a relatively narrow range $(2.5 \%$ o in $\delta^{13} \mathrm{C}$ values but a wide range $(9.1 \% \circ)$ in $\delta^{15} \mathrm{~N}$, due to the presence of an extreme outlier from Carrer Sant Vicent, VSVC3622 (Table 2). The $\delta^{13} \mathrm{C}$ and $\delta^{15} \mathrm{~N}$ values for the majority indicate a $\mathrm{C}_{3}$ terrestrial-based diet with animal protein deriving from herbivores and little contribution from pigs, which have values similar to the humans themselves (Fig. 3, human $\delta^{15} \mathrm{~N}$ values are on average only $1.8 \%$ o higher in than the mean for pigs). However, there may be an additional source of ${ }^{13} \mathrm{C}$-enriched carbon and ${ }^{15} \mathrm{~N}$-enriched nitrogen in the diet of some individuals, perhaps from $\mathrm{C}_{4}$ fed pork or marine sources.

Inter-site comparison in Valencia is limited by San Andrés being represented by just four individuals (Fig. 8). One group of four individuals from the Sant Vicent cemetery are identifiable as possessing $\delta^{15} \mathrm{~N}$ values that are on par with some of the higher herbivore values. Their consumption of animal protein was therefore limited, and they were probably poor people housed by the hospital at the Sant Vicent complex.
The outlier from Carrer Sant Vicent, VSVC3622, with a remarkably high $\delta^{15} \mathrm{~N}$ value of $17 \%$ lacks a corresponding enrichment in ${ }^{13} \mathrm{C}$, which rules out the consumption of marine fish. This extreme $\delta^{15} \mathrm{~N}$ value is unlikely to represent a local who consumed freshwater fish, given that the value is higher than even Mesolithic individuals who are hypothesised to have primarily subsisted on freshwater fish from the Danube (Bonsall et al. 2004). A recent study of an Islamic population from Aragón (eighth-tenth century), however, showed similar $\delta^{15} \mathrm{~N}$ values (mean of $15 \%$ ) correlated with a $\mathrm{C}_{3}$ carbon value (mean $-19.1 \%$ o) so that such signatures are possible in some areas of Spain (Guede et al. 2017). Although data from later Christian periods are lacking from that area, northern Aragón is a possible place of origin that ties with population movement during the initial phase of Christian control and repopulation of Valencia. However, any other area with high aridity and $\mathrm{C}_{3}$ crops remains a possibility.

Across the Valencian region (Fig. 5), there is a greater reliance of on $\mathrm{C}_{4}$ plants exhibited by the broadly contemporaneous Christian population from Gandía and the mudéjar

Table 5 Summary $\delta^{13} \mathrm{C}$ and $\delta^{15} \mathrm{~N}$ data for animals for each period in medieval Valencia

\begin{tabular}{|c|c|c|c|c|c|c|c|c|c|c|}
\hline \multirow[t]{2}{*}{ Period (centuries) } & \multirow[t]{2}{*}{ Species } & \multirow[t]{2}{*}{$n$} & \multicolumn{4}{|c|}{$\delta^{13} \mathrm{C}_{\mathrm{VPDB}}(\% \circ)$} & \multicolumn{4}{|c|}{$\delta^{15} \mathrm{~N}_{\mathrm{AIR}}(\% \circ)$} \\
\hline & & & Min & Max & Range & Mean $\pm 1 \sigma^{\mathrm{a}}$ & Min & Max & Range & Mean $\pm 1 \sigma^{\mathrm{a}}$ \\
\hline \multirow[t]{5}{*}{ Visigothic, 5th-7thC } & Cow & 2 & -20.1 & -18.6 & 1.5 & -19.3 & 3.7 & 3.9 & 0.2 & 3.8 \\
\hline & Ovicaprid & 5 & -20.5 & -18.9 & 1.6 & $-19.8 \pm 0.6$ & 3.7 & 7.4 & 3.8 & $5.6 \pm 1.4$ \\
\hline & Pig & 3 & -19.4 & -18.5 & 0.8 & $-19.0 \pm 0.4$ & 7.2 & 8.5 & 1.4 & $8.0 \pm 0.8$ \\
\hline & Rabbit & 1 & - & - & - & -22.3 & - & - & - & 3.7 \\
\hline & Dog & 1 & - & - & - & -16.4 & - & - & - & 9.0 \\
\hline \multirow[t]{4}{*}{ Islamic, 11th-13thC } & Cow & 5 & -20.1 & -15.8 & 4.3 & $-18.0 \pm 1.7$ & 2.5 & 8.5 & 6.0 & $6.2 \pm 2.3$ \\
\hline & Ovicaprid & 8 & -20.4 & -18.6 & 1.8 & $-19.5 \pm 0.6$ & 2.8 & 9.7 & 6.9 & $6.5 \pm 2.6$ \\
\hline & Pig & 1 & - & - & - & -19.5 & - & - & - & 7.7 \\
\hline & Chicken & 2 & -17.9 & -10 & 7.9 & - & 11.4 & 11.5 & 0.1 & 11.4 \\
\hline \multirow[t]{4}{*}{ Christian, 14th-15thC } & Cow & 2 & -20.6 & -19.9 & 0.7 & -20.2 & - & - & - & 7.5 \\
\hline & Ovicaprid & 7 & -20.7 & -19.3 & 1.4 & $-20.0 \pm 0.6$ & 3.0 & 8.0 & 5.0 & $5.5 \pm 1.8$ \\
\hline & Pig & 4 & -19.6 & -17.0 & 2.6 & $-18.6 \pm 1.2$ & 8.0 & 9.6 & 1.6 & $8.8 \pm 0.7$ \\
\hline & Rabbit & 1 & - & - & - & -21.8 & - & - & - & 4.6 \\
\hline
\end{tabular}

${ }^{\text {a }}$ Standard deviation only calculated for three or more samples 


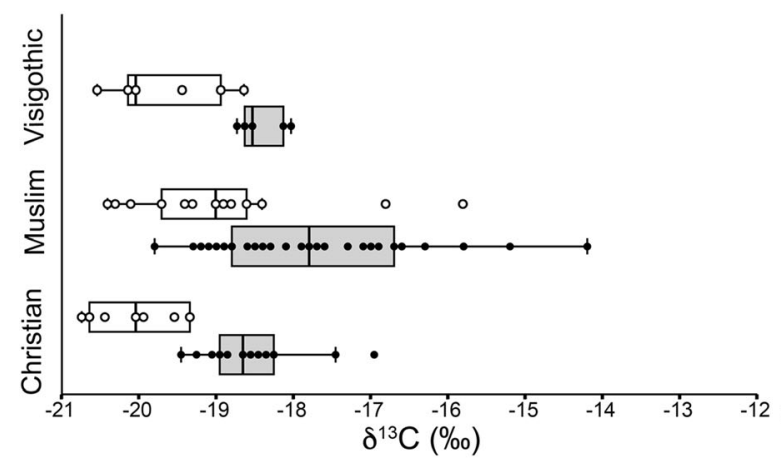

Fig. 4 Stable carbon and nitrogen isotope data for herbivore (cattle, sheep/goat, white boxes) and human (grey boxes) bone collagen plotted by period as box and jitter plots. The boxes indicate the inter-quartile range (IQR), the whiskers comprise the values that are with $1.5 \times$ the

populations of Benipeixcar and El Raval (Alexander et al. 2015; Salazar-García et al. 2014) in comparison to the inhabitants of Christian Valencia. This may again reflect a difference between urban and rural subsistence in this later phase. During the thirteenth and fourteenth centuries, the city of Valencia itself had authority over cereal production and distribution (Barrio 2009, p. 63) but in times of shortage of wheat grain was imported from outside the kingdom (García Marsilla 1993, p. 7). Because of this, it is highly probable that the availability of wheat in the more rural areas was limited to those who could afford it. The bulk of the populace would have had to (or chosen to) rely on grains produced locally, including millet or sorghum.

\section{Discussion and synthesis}

Although sample sizes are relatively small for the Visigothic and, to some extent, later Christian periods, the consistency of the core isotopic data for all periods $\left(\sim-19\right.$ to $-17 \% \circ \delta^{13} \mathrm{C}, \sim$ 10 to $12 \%$ o $\delta^{15}$ N, Fig. 3 ) and the stark contrast we see in the Islamic period in particular lends support to our interpretations.

\section{Diachronic trends}

The diet for the majority of the sampled population was characterised by a reliance on terrestrial $\mathrm{C}_{3}$ resources which

Table 6 Herbivore-human average offsets for mean $\delta^{13} \mathrm{C}$ and $\delta^{15} \mathrm{~N}$ for all periods, Visigothic (5th-7th centuries), Islamic (11th-13th centuries) and Christian (14th and 15th centuries)

\begin{tabular}{lllll}
\hline Period & $n$ (cattle/sheep/goat) & $n$ (human) & $\Delta^{13} \mathrm{C}$ & $\Delta^{15} \mathrm{~N}$ \\
\hline Christian & 9 & 19 & 1.6 & 4.9 \\
Muslim & 11 & 38 & 1.2 & 5.2 \\
Visigothic & 7 & 10 & 1.2 & 5.7 \\
\hline
\end{tabular}

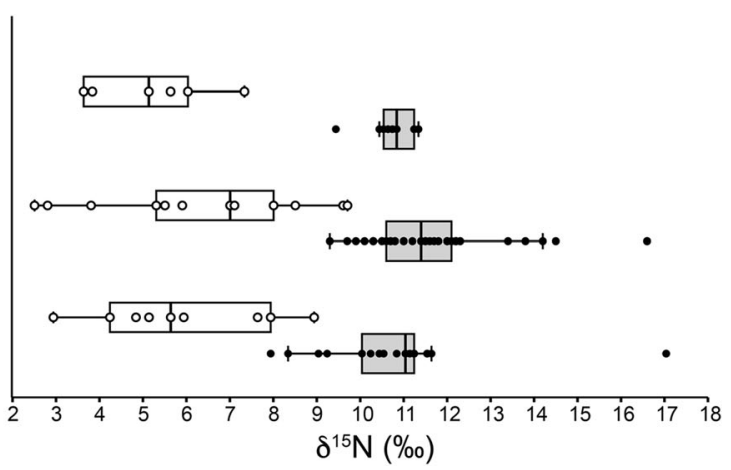

IQR and the dots beyond these are outliers. Sample numbers: herbivores 7, 13, 9 and humans 10, 38, 18, for Visigothic, Islamic and Christian respectively

is similar throughout all three periods under discussion. Despite this, significant shifts in subsistence occurred between each phase, which can be linked to cultural and socioeconomic changes in the historic record. The Islamic period is noteworthy for a wide variation in isotopic values and the greater reliance on $\mathrm{C}_{4}$ crops compared to the periods both before and after.

The variability in subsistence exhibited by the Islamic population may reflect an increased non-local presence in the population, made visible by migrants from more arid areas where $\mathrm{C}_{4}$ crops were cultivated, such as the Maghreb. When Christians took control of much of the Iberian Peninsula from the thirteenth century onwards, there was some reorientation of trade towards northern Christian Europe although some trade links between the Sultanate of Granada and the Islamic Maghreb did continue, if diminished (Constable 1994; Ferrer 2012). This change in trade may have had an impact on the origin of travellers, merchants and traders present in the city. The presence of African slaves, however, continued into the Christian period and Valencia became the principal port for the import and export of slaves in the western Mediterranean (Montalvo 2000; Mummey and Reyerson 2011; Ferrer 2012).

The shift towards the greater use of $\mathrm{C}_{4}$ crops among local humans and animals in the Islamic period is another factor behind diversity in isotopic values that may be linked to the use of crops such as sorghum (Watson 1974; Squatriti 2014). In a recent survey of available archaeobotanical data for the Iberian Peninsula, it was reported that evidence for millets has been recorded on many medieval sites particularly in the west/ north-west and the north-east although the archaeobotanical evidence from Valencia itself is extremely patchy and does not extend into the Christian period (Peña-Chocarro et al. 2017). Sorghum is yet to be identified at any site, although evidence has been found in medieval France and North Africa (PeñaChocarro et al. 2017). It is not until the Christian period (fourteenth and fifteenth centuries) that we have historical records confirming the presence of $\mathrm{C}_{4}$ crops such as sorghum in the Horta of Valencia, where a white form was used primarily for 
Fig. 5 Mean values for stable carbon and nitrogen isotope data for human bone collagen for the later medieval period published from southern and eastern Spain and Ibiza. Error bars represent \pm $1 \sigma$. References: Gandía and Benipeixcar (Alexander et al. 2015), El Raval (Salazar-García et al. 2014), Tossal de les Basses (Salazar-García et al. 2016), La Torrecilla and Seville Royalty (Jiménez-Brobeil et al. 2016), Can Fonoll (Pickard et al. 2017), Es Soto and S'Hort des Llimoners (Fuller et al. 2010)

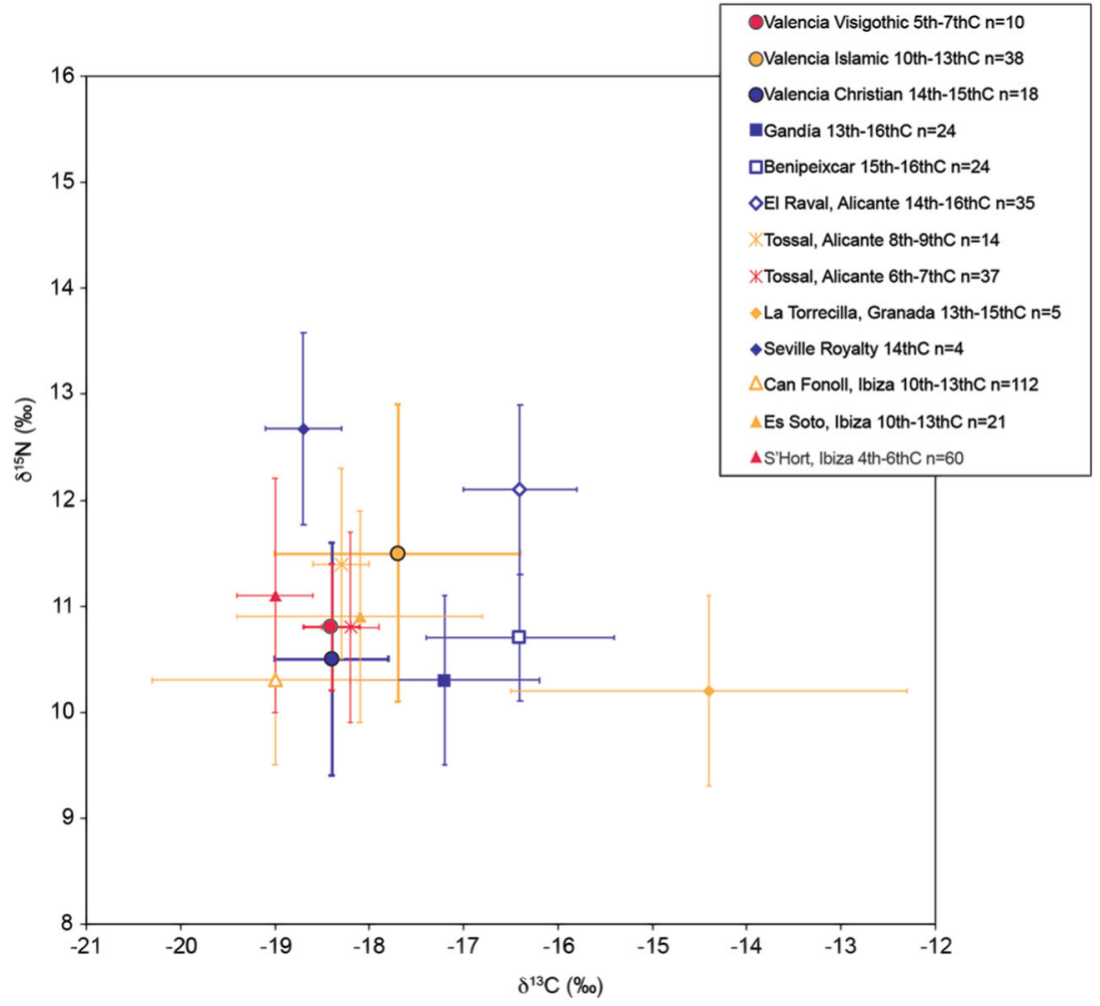

human consumption, and a red variety was used as a fodder for cattle and poultry (Rubio 1995, p. 169). Focus on wheat as the most profitable commercial crop, however, meant that summer grains such as millet and sorghum may have been more limited for the tenants of the irrigated Horta (Torro 2009a). The lower $\delta^{13} \mathrm{C}$ values exhibited by humans and animals in the Christian population confirm a decrease in $\mathrm{C}_{4}$ plant consumption, perhaps reflecting a decline in millet and sorghum cultivation during this period.

Socio-cultural factors may have also combined with these economic circumstances. Following the thirteenth-century Christian conquest, the newly arrived population would have comprised of settlers from northern Christian kingdoms, principally Aragón, who were encouraged to migrate by the offer of reduced taxes and enhanced privileges (Burns 1975; Ruiz 2014). Written sources suggest that $C_{4}$ plants were regarded as minority crops in these regions (Aguilera 1991, p. 9; Glick 1982, p. 82), although isotopic data does reveal a reliance on millet in other areas of northern Spain such as Galicia (Kaal et al. 2016; López-Costas and Müldner 2016) and the Basque Country (Quirós Castillo 2013). As a result, the consumption of $\mathrm{C}_{4}$ crops such as sorghum may have decreased after the Christians took control, at least among the urban population (Rubio 1995, p. 162).

The growing picture of diet in southern and eastern regions of Spain (Fig. 5) suggests that, despite millet being present in the Iberian Peninsula since the Middle Bronze Age (Buxó and Piqué 2008), $\mathrm{C}_{4}$ crops only rose in importance as a food source in these areas during the period of Islamic rule. This is evidenced in the comparatively low $\delta^{13} \mathrm{C}$ values seen so far in Late Antique/Visigothic populations and may not have occurred immediately after the Islamic conquest as the largely $\mathrm{C}_{3}$ diet of the earlier eighth- and ninth-century site in Alicante site attests (Salazar-García et al. 2016). Although $\mathrm{C}_{4}$ crops continued to be grown under later Christian rule, their

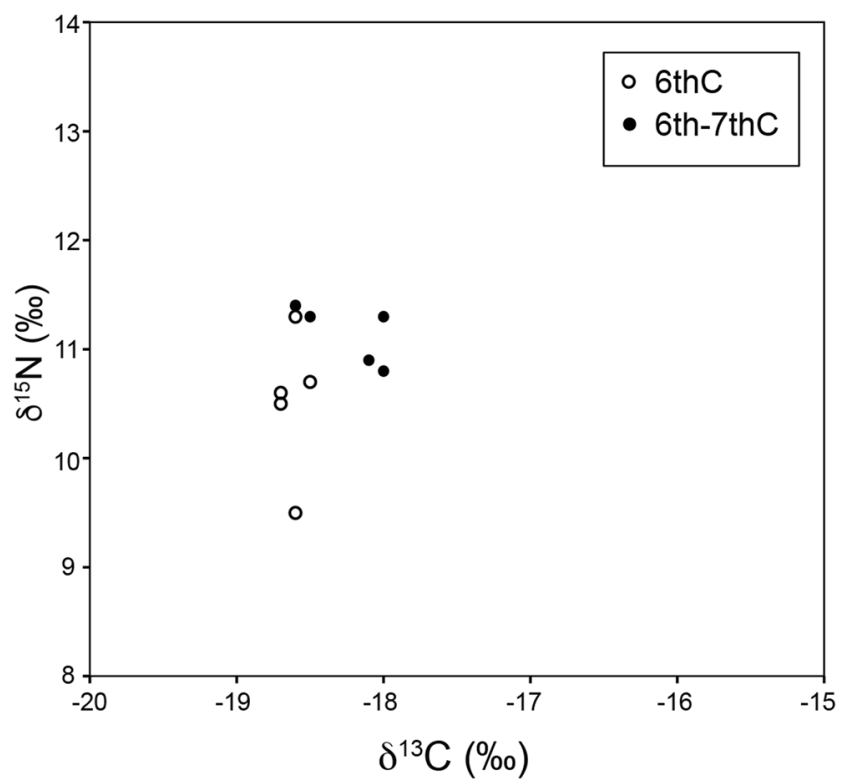

Fig. 6 Stable carbon and nitrogen isotope data for human bone collagen from the Visigothic period (5th-7th century) separated by phase 


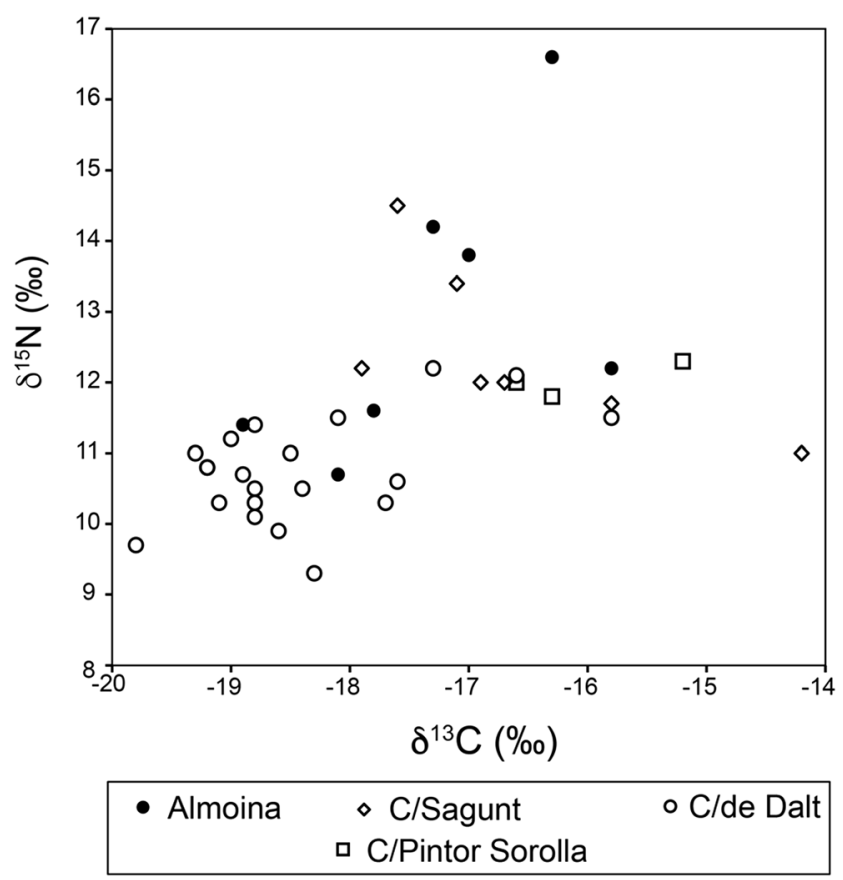

Fig. 7 Stable carbon and nitrogen isotope data for human bone collagen from the sites of Almoina, Carrer Sagunt, Carrer Pintor Sorolla and Carrer de Dalt (Bab al-Hanax) in the Muslim period (11th-13th century)

importance was diminished and seems firmly associated with the lower social orders and rural populations.

Despite faunal data exhibiting high variation in all periods, shifts in isotopic values were detected, indicating a baseline economic shift and husbandry between all three periods. While there may have been much continuity in husbandry between periods, the scale of agriculture and animal husbandry differed with changing production strategies and reorganisation of agricultural landscapes, particularly during the later Christian period (Torró 2012b; Lopez and Retamero 2017). As mentioned above, there was a shift in economic strategy towards a more intensive focus on economic crops and an emphasis on animal livestock and long-range transhumance (Montalvo 1992; Trillo San José 1999; Malpica 2012). It is in the later Christian period that large sheep flocks were driven through the peninsula from Aragón and Castile to the lowland pastures of southern Valencia (Klein 1920; Butzer 1988; Montalvo 1992). Similarly, cattle ranching had developed earlier in the northern Christian kingdoms and was introduced to Valencia in the thirteenth century. Herds from Valencia were driven to grazing pastures some $170 \mathrm{~km}$ to the south at Elche (O'Callaghan 1975, p. 478; Montalvo 1992, p. 169). This change towards large-scale animal husbandry in the Christian period may serve to lessen the variability in livestock practices and homogenise dietary signals among livestock when compared to the Islamic period. For example, transhumant cattle and sheep flocks driven between summer and winter grazing lands would have effectively fed on $\mathrm{C}_{3}$ pastures all year round which may have led to a decline in $\mathrm{C}_{4}$ fodder fed to local sedentary animals. This would particularly have been the case at times of the year when there was only poor-quality local pasture available. To determine whether the differences in livestock practices suggested here are truly significant, further samples would need to be analysed from different quarters of the city and be combined with zooarchaeological study.

Although the isotopic data indicate the potential for certain individuals to have consumed marine resources in the Islamic period, the lack of evidence for significant marine fish consumption for the later Christian period is somewhat surprising, particularly given that fish would have fulfilled a liturgical requirement. Port archives of the fifteenth century indicate the importance of fishing to the city, mentioning the availability of 27 different types of marine and freshwater fish (Guiral 1989, p. 381). Fresh fish either originated from the Mediterranean or from brackish lagoons such as the Albufera; sardines in particular were a cheap fish that could be afforded by those of little wealth in Valencia during this period (Granero and Amparo 1962; Gallart et al. 2005; García Marsilla 1993). The dietary contribution of low trophic level marine fish and minor quantities of marine and especially brackish resources is, however, difficult to detect using isotopic analysis, particularly for the Mediterranean (Garvie-Lok 2001; Hedges 2004; Triantaphyllou et al. 2008). There is only one published instance of increased fish consumption in the later medieval period in the

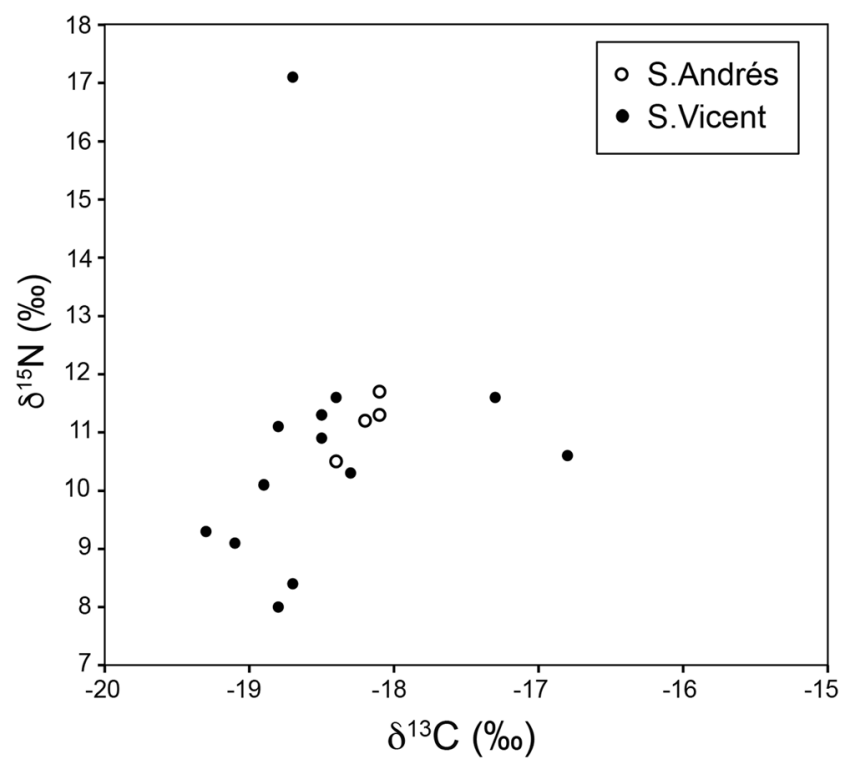

Fig. 8 Stable carbon and nitrogen isotope data for human bone collagen from San Andrés and Sant Vicent sites in the Christian period (14th and 15 th century) 
Mediterranean, from fifteenth-century Rome, where the consumption of traded Atlantic fish has been hypothesised (Salamon et al. 2008). Valencia and Alicante served as redistribution centres for fish caught in Galicia and being transported inland to Castile and Aragón (Ferreira 1988), although high trophic level Atlantic fish with corresponding higher $\delta^{15} \mathrm{~N}$ values (e.g. López-Costas and Müldner 2016) do not appear to have been a major component in the diet. The isotopic results particularly for the later Christian period in Valencia might be sufficient to question how far marine resources contributed to the local diet in the city.

It is notable that no differentiation in diet was detected between sexes at any period, something which is not reported universally in stable isotope studies of medieval populations. This may be due to a lack of dietary differentiation despite the differing roles of males and females purported for medieval Muslim and Christian societies, where women were typically associated with food preparation and domestic tasks (Shatzmiller 1994; Ward 2002). On the other hand, this may simply reflect the broad nature of isotopic evidence for diet and/or the small sample sizes often involved in such comparisons.

\section{Conclusion}

Diet in Valencia over 1000 years is characterised by significant isotopic variability between Visigothic, Muslim and later medieval Christian individuals, revealing distinct dietary regimes between these culturally contrasting phases of medieval Valencia. Diachronic trends in the data support historical evidence for a significant change in diet and subsistence, particularly during the Muslim and later Christian periods. Differences in both human and animal data between periods are the result of a complex interplay of factors including socioeconomic shifts and developing travel and trade routes.

Although many individuals in the Islamic period have isotopic values which are similar to those exhibited by individuals in the earlier Visigothic period, there is a far greater range in the $\delta^{13} \mathrm{C}$ and $\delta^{15} \mathrm{~N}$ values of the Muslim population. This may be due to an increased number of migrants from areas with distinctive enrichment of foods in ${ }^{13} \mathrm{C}$ and ${ }^{15} \mathrm{~N}$ such as the Maghreb, to which Valencia was politically and culturally aligned in this period. This diversity in values also almost certainly reflects the variety in choice or access to isotopically distinct foods at this time, as wells as the introduction of new crops, an emphasis on polyculture and the balance of local herding and cereal farming in the region. The growth of urban Valencia under Islamic rule may also have encouraged diversification, particularly the introduction of $\mathrm{C}_{4}$ crops to the diets of both humans and animals. These foodstuffs are traditionally associated with lower status social groups and have the effect of increasing the isotopic 'visibility' of socioeconomic differences among the populations sampled here, although issues around the detection of marine protein consumption obscure a clear interpretation.

A reduction in observed dietary diversity in the Christian period may be linked with a change in economic focus, both in terms of the reorganisation of trade routes but also agriculture and animal husbandry. The transition to Christian feudal rule emphasised commercial crops and flocks, potentially homogenising isotopic values, although rural and urban differences in the use of $\mathrm{C}_{4}$ crops remained. Given the reorientation of trade routes, people from the medieval Islamic world with dietary isotopic signatures indicative of $\mathrm{C}_{4}$ consumption and/or living in arid environments were less likely to be present in the city.

The potential for differential consumption of marine fish complicating the subsistence patterns interpreted here cannot be disregarded although identifying this with bulk isotope analysis is confounded by the $\mathrm{C}_{4}$ animal protein/ Mediterranean fish phenomenon. In the future, techniques utilising compound-specific analysis of bone collagen amino acid $\delta^{13} \mathrm{C}$ could be implemented to identify diets with high marine protein input (Corr et al. 2005). These developing techniques, combined with a thorough regional review of existing medieval archaeozoological and archaeobotanical datasets, offer the best prospect for the future.

Acknowledgements The authors gratefully acknowledge Pepa Pascual (Servicio de Investigación Arqueológica Municipal de Valencia) and Javier Martí (Museo de Historia de Valencia) for all their help and enabling access to the skeletal collections in Valencia. Thanks to Olaf Nehlich (MPI-EVA) for consultation and collagen preparation and analysis. Thanks go to Helen Goodchild (University of York) for aid in ARCGIS. We are also grateful to the reviewers for their constructive comments on the manuscript.

Funding information This research was funded by an AHRC PhD studentship awarded to Alexander (ref: 2006/125150/University of Durham) with contributions from a Durham Doctoral Fellowship and a Society for Medieval Archaeology Eric Fletcher Fund Award.

Open Access This article is distributed under the terms of the Creative Commons Attribution 4.0 International License (http:// creativecommons.org/licenses/by/4.0/), which permits unrestricted use, distribution, and reproduction in any medium, provided you give appropriate credit to the original author(s) and the source, provide a link to the Creative Commons license, and indicate if changes were made.

Publisher's note Springer Nature remains neutral with regard to jurisdictional claims in published maps and institutional affiliations.

\section{References}

Adamson MW (2004) Food in medieval times. Greenwood Press, Connecticut \& London 
Aguilera J (1991) La cocina hispano-árabe y las cocinas españolas y del norte de África. Darek-Nyumba, D.L., Madrid

Albiach R, Badia Á, Calvo M, Marín C, Ribera A (1998) Memòria de l'excavació arqueológica al solar de L'Almoina (Valencia). $8^{\mathrm{a}}$ Campaña. Ayuntamiento de Valencia, Valencia

Alexander MM, Gerrard CM, Gutiérrez A, Millard AR (2015) Diet, society, and economy in late medieval Spain: stable isotope evidence from Muslims and Christians from Gandía, Valencia. Am J Phys Anthropol 156(2):263-273

Álvarez N, Ribera A (2002) Informe arqueológico de la excavación de L'Almoina (Valencia). 11 ${ }^{\mathrm{a}}$ Campaña. Ayuntamiento de Valencia, Valencia

Barrio JA (2009) La producción, el consumo y la especulación de los cereales en una ciudad de frontera: Orihuela, siglos XII-XIV. In: Arízaga B, Solárzano JA (eds) Alimentar la ciudad en la Edad Media. Instituto de Estudios Riojanos, Logroño, pp 59-86

Baydal V, Esquilache F (2014) Exploitation and differentiation: economic and social stratification in the rural Muslim communities of the Kingdom of Valencia, 13th-16th centuries. In: Aparisi F, Royo V (eds) Beyond lords and peasants: rural elites and economic differentiation in pre-modern Europe. Publicacions de la Universitat de Valencia, Valencia, pp 37-67

Bocherens H, Drucker D (2003) Trophic level isotopic enrichment of carbon and nitrogen in bone collagen: case studies from recent and ancient terrestrial ecosystems. Int J Osteoarchaeol 13(1-2):46-53

Bogaard A, Heaton TH, Poulton P, Merbach I (2007) The impact of manuring on nitrogen isotope ratios in cereals: archaeological implications for reconstruction of diet and crop management practices. J Archaeol Sci 34(3):335-343

Bonsall C, Cook GT, Hedges REM, Higham TFG, Pickard C, Radovanovic I (2004) Radiocarbon and stable isotope evidence of dietary change from the Mesolithic to the Middle Ages in the Iron Gates: new results from Lepenski Vir. Radiocarbon 46:293-300

Boone JL, Benco NL (1999) Islamic settlement in North Africa and the Iberian Peninsula. Ann Rev Anthropol 28:51-71

Britton K, Müldner G, Bell M (2008) Stable isotope evidence for saltmarsh grazing in the Bronze Age Severn Estuary, UK: implications for palaeodietary analysis at coastal sites. J Archaeol Sci 35(8): 2111-2118

Brothwell DR (1981) Digging up bones. Cornell University Press, New York

Brown TA, Nelson DE, Vogel JS, Southon JR (1988) Improved collagen extraction by modified Longin method. Radiocarbon 30:171-177

Burns RI (1967) The Crusader Kingdom of Valencia: reconstruction of a thirteenth-century frontier, volume 1. Harvard University Press, Cambridge, Mass

Burns RI (1975) Immigrants from Islam: the crusaders' use of Muslims as settlers in thirteenth-century Spain. Am Hist Rev 80:21-42

Butzer KW (1988) Cattle and sheep from Old to New Spain: historical antecedents. Ann Assoc Am Geogr 78(1):29-56

Buxó R, Piqué R (2008) Arqueobotánica: los usos de las plantas en la Peninsula Ibérica. Ariel prehistoria, Barcelona

Christie N, Beavitt P, Gisbert JA, Seguí J, Gil MV (2004) Ethnography and archaeology in upland Mediterranean Spain. School of Archaeology and Ancient History, University of Leicester, Leicester

Constable OR (1994) Trade and traders in Muslim Spain. Cambridge University Press, Cambridge

Constable OR (1996) Muslim Spain and Mediterranean slavery: the medieval slave trade as an aspect of Muslim-Christian relations. In Waugh SL, Diehl PD (eds) Christendom and its discontents. Exclusion, persecution and rebellion, 10001500. Cambridge University Press, Cambridge, pp 264-284

Coplen TB (2011) Guidelines and recommended terms for expression of stable-isotope-ratio and gas-ratio measurement results. Rapid Commun Mass Spectrom 25(17):2538-2560
Corr LT, Sealy JC, Horton MC, Evershed RP (2005) A novel marine dietary indicator utilising compound-specific bone collagen amino acid $\delta^{13} \mathrm{C}$ values of ancient humans. J Archaeol Sci 32(3):321-330

Craig OE, Bondioli L, Fattore L, Higham T, Hedges R (2013) Evaluating marine diets through radiocarbon dating and stable isotope analysis of victims of the AD79 eruption of Vesuvius. Am J Phys Anthropol 152(3):345-352

de Castro T (1993) La alimentación en las crónicas castellanas bajomedievales. Universidad de Granada, Granada

Decker M (2009) Plants and progress: rethinking the Islamic agricultural revolution. J World Hist 20(2):187-206

DeNiro MJ (1985) Postmortem preservation and alteration of in vivo bone collagen isotope ratios in relation to palaeodietary reconstruction. Nature 317:806-809

Dupras TL, Schwarcz HP (2001) Strangers in a strange land: stable isotope evidence for human migration in the Dakhleh Oasis, Egypt. J Archaeol Sci 28(11):1199-1208

Estaca-Gómez V, Malalana-Ureña A, Yravedra J, Matás GJL, de Pablos JM (2018) Economic implications of livestock management strategies in the center of the Iberian Peninsula, Tagus Basin, and Mancha Alta region between the VIII and XI centuries AD. Archaeol Anthropol Sci:1-17. https://doi.org/10.1007/s12520-018-0607-9

Ferreira E (1988) Galicia en el comercio marítimo medieval. Colección de documentos históricos, La Coruña

Ferrer MT (2012) Catalan commerce in the later Middle Ages. Catalan Historical Review, 29-65

Fuller BT, Márquez-Grant N, Richards MP (2010) Investigation of diachronic dietary patterns on the islands of Ibiza and Formentera, Spain: evidence from carbon and nitrogen stable isotope ratio analysis. Am J Phys Anthropol 143(4):512-522

Gallart L, Roberto IE, Maupoei PF (2005) La salazón de pescado, una tradición en la dieta mediterránea. Universidad Politécnica de Valencia, Valencia

García Marsilla JV (1993) La jerarquía de la mesa. Centre d'Estudis d'Història Local, Valencia

García MI, Ruiz E (1997) Informe arqueológico preliminar Calle Pintor Sorolla, $\mathrm{N}^{\mathrm{o}} 5$ y 7 de Valencia. Ayuntamiento de Valencia, Valencia

García Sánchez E (1996) La alimentación popular urbana en al-Andalus. Arqueología Medieval 4:219-235

García Sánchez E (2002) Dietic aspects of food in al-Andalus. In: Waines D (ed) Patterns of everyday life: the formation of the classical Islamic world, vol 10. Ashgate, Aldershot, pp 275-288

Garvie-Lok S (2001) Loaves and fishes: a stable isotope reconstruction of diet in medieval Greece. Unpublished $\mathrm{PhD}$ dissertation. University of Calgary, Alberta

Gerrard CM (2003) Paisaje y señorío. La casa conventual de Ambel (Zaragoza): arqueología, arquitectura e historia de las Órdenes militares del Temple y del Hospital. Institución Fernando el Católico, Zaragoza

Glick TF (1982) Agriculture and nutrition: the Mediterranean region. In: Strauyer R (ed) Dictionary of the Middle Ages. Charles Scribner's Sons for the American Council of Learned Societies, New York, pp $79-88$

Glick TF (1995) From Muslim fortress to Christian castle: social and cultural change in medieval Spain. Manchester University Press, Manchester

Glick TF (2005) Islamic and Christian Spain in the Early Middle Ages. Brill, Leiden

Granero C, Amparo M (1962) Abastecimientos de la ciudad de Valencia durante la Edad Media. Saitabi 12:1-27

Grau-Sologestoa I (2017) Socio-economic status and religious identity in medieval Iberia: the zooarchaeological evidence. Environ Archaeol 22(2):189-199

Guede I, Ortega LA, Zuluaga MC, Alonso-Olazabal A, Murelaga X, Pina M, Gutiérrez FJ, Iacumin P (2017) Isotope analyses to explore diet 
and mobility in a medieval Muslim population at Tauste (NE Spain). PLoS One 12(5): 0176572

Guichard P (2000) Al-Andalus (711-1492). Hachette Littératures, Paris

Guinot E (2009) La construcción de una ciudad feudal: Valencia (12381300). In: Hermosilla Pla J (ed) La ciudad de Valencia, historia, geografía y arte de la ciudad de Valencia. Vol. 1: Historia. Universitat de Valencia, Valencia, pp 169-179

Guinot E, Esquilache F (2017) Not only peasants: the myth of continuity in the irrigation communities of Valencia, Spain, in the medieval and early modern periods. Contin Chang 32(2):129-156

Guiral J (1989) Valencia puerto mediterráneo en el siglo XV (1410 1525). Edicions Alfons el Magnànim, Valencia

Guiry EJ (2012) Dogs as analogs in stable isotope-based human paleodietary reconstructions: a review and considerations for future use. J Archaeol Method Theory 19(3):351-376

Hammer Ø, Harper D, Ryan PD (2001) PAST: paleontological statistics software package for education and data analysis. Palaeontol Electron 4:9

Heaton $\mathrm{T}(1987)$ The ${ }^{15} \mathrm{~N} /{ }^{14} \mathrm{~N}$ ratios of plants in South Africa and Namibia: relationship to climate and coastal/saline environments. Oecologia 74:236-246

Hedges REM (2004) Isotopes and red herrings: comments on Milner et al. \& Lidén et al. Antiquity 78(299):34-37

Hedges REM, Thompson J, Hull BD (2005) Stable isotope variation in wool as a means to establish Turkish carpet provenance. Rapid Commun Mass Spectrom 19(22):3187-3191

Hedges REM, Clement JG, Thomas CDL, O'Connell TC (2007) Collagen turnover in the adult femoral mid-shaft: modeled from anthropogenic radiocarbon tracer measurements. Am J Phys Anthropol 133(2):808-816

Herreros A (1999) Excavación realizada en la Calle Sagunto no. 165 y 167 de Valencia. Ayuntamiento de Valencia, Valencia

Hidalgo JG, De Luis M, Raventós J, Sánchez JR (2003) Daily rainfall trend in the Valencia Region of Spain. Theor Appl Climatol 75(1-2): $117-130$

Jiménez Salvador JL (2009) La ciudad visigoda: un nuevo paisaje urbano. In: Hermosilla Pla J (ed) La ciudad de Valencia, historia, geografía y arte de la ciudad de Valencia. Vol. 1: Historia. Universitat de Valencia, Valencia, pp 139-147

Jiménez-Brobeil SA, Laffranchi Z, Maroto RM, Sánchez FL, Huertas AD (2016) How royals feasted in the court of Pedro I of Castile: a contribution of stable isotope study to medieval history. J Archaeol Sci Rep 10:424-430

Jørkov MLS, Heinemeier J, Lynnerup N (2007) Evaluating bone collagen extraction methods for stable isotope analysis in dietary studies. J Archaeol Sci 34(11):1824-1829

Kaal J, López-Costas O, Martínez Cortizas A (2016) Diagenetic effects on pyrolysis fingerprints of extracted collagen in archaeological human bones from NW Spain, as determined by pyrolysis-GC-MS. J Archaeol Sci 65:1-10

Katzenberg MA (2000) Stable isotope analysis: a tool for studying past diet, demography and history. In: Katzenberg MA, Saunders SR (eds) Biological anthropology of the human skeleton. Wiley Periodicals, New York, pp 305-328

Kennedy H (1996) Muslim Spain and Portugal: a political history of alAndalus. Longman, London

Klein J (1920) The Mesta: a study in Spanish economic history 12731836. Harvard University Press, Cambridge

Lee-Thope JA (2008) On isotopes and old bones. Archaeometry 50(6): 925-950

Lightfoot E, Slaus M, O’Connell TC (2012) Changing cultures, changing cuisines: cultural transitions and dietary change in Iron Age, Roman, and Early Medieval Croatia. Am J Phys Anthropol 148:543-556

Longin R (1971) New method of collagen extraction for radiocarbon dating. Nature 230:241-242
Lopez E, Retamero F (2017) Segregated fields. Castillian and Morisco peasants in Moclón (Málaga, Spain, sixteenth century). Int J Hist Archaeol:1-18. https://doi.org/10.1007/s10761-016-0390-1

López-Costas O, Müldner G (2016) Fringes of the empire: diet and cultural change at the Roman to post-Roman transition in NW Iberia. Am J Phys Anthropol 161(1):141-154

Lozoya MC, Gallego RS, Pérez JP (2006) Ensayo de rituales de enterramiento islámicos en al-Andalus. Anales de prehistoria y arqueología 22:153-164

Malpica A (2012) La vida agrícola y la ganadería en al-Andalus y en el reino nazarí de Granada. In: Marín López R (ed) Homenaje al Profesor José Ignacio Fernández de Viana. University of Granada, Granada, pp 213-228

Martin L, Ribera AV (2006) Cementerios tardoantiguos de Valencia: arqueología y antropología. Arqueol Cordobesa 17(2):161-194

Mays S, Cox M (2000) Sex determination in skeletal remains. In: Cox M, Mays S (eds) Human osteology in archaeology and forensic science. Cambridge University Press, London, pp 117-130

Momblanch FP (2003) Historia de la Albufera de Valencia. Ayuntamiento de Valencia, Valencia

Montalvo JH (1992) Aproximación a la ganadería alicantina en la Edad Media. Anales de la Universidad de Alicante, Historia medieval 9: $161-178$

Montalvo JH (2000) Esclavos, nobles y corsarios en el Alicante medieval. In: De la esclavitud a la libertad en el reino de Valencia durante los siglos medievales. CSIC, Barcelona, pp 431-71

Montserrat P, Fillat F (1990) The systems of grassland management in Spain. In: Breymeyer AI (ed) Managed grasslands: regional studies, ecosystems of the world v.17A. Elsevier Publications, Amsterdam, pp. $37-70$

Morales A, Moreno-García M, Roselló E, Llorente L, Morales DC (2011) 711 AC: ¿el origen de una disyunción alimentaria? Zona Arqueológica 15(2):303-322

Moreno A, Pérez A, Frigola J, Nieto-Moreno V, Rodrigo-Gámiz M, Martrat B, González-Sampériz P, Morellón M, Martín-Puertas C, Corella JP, Belmonte Á (2012) The medieval climate anomaly in the Iberian Peninsula reconstructed from marine and lake records. Quat Sci Rev 43:16-32

Moreno-Larrazabal A, Teira-Brión A, Sopelana-Salcedo I, ArranzOtaegui A, Zapata L (2015) Ethnobotany of millet cultivation in the north of the Iberian Peninsula. Veg Hist Archaeobotany 24(4): $541-554$

Müldner G, Richards MP (2007) Stable isotope evidence for 1500 years of human diet at the city of York, UK. Am J Phys Anthropol 133(1): 682-697

Mummey K, Reyerson K (2011) Whose city is this? Hucksters, domestic servants, wet-nurses, prostitutes, and slaves in late medieval western Mediterranean urban society. History Compass 9(12):910-922

O'Callaghan JF (1975) A history of medieval Spain. Cornell University Press, Ithaca and London

O'Connell TC, Kneale CJ, Tasevska N, Kuhnle GG (2012) The diet-body offset in human nitrogen isotopic values: a controlled dietary study. Am J Phys Anthropol 149(3):426-434

O'Leary MH (1981) Carbon isotope fractionation in plants. Phytochemistry 20(4):553-567

Ortega D, Gálego A (2004) Informe preliminar de la intervención arqueológica en la C/ Sant Vicent 134, Valencia. Ayuntamiento de Valencia, Valencia

Pascual J (1989) La necropólis islámica de L’Almoina (Valencia). Primeros resultados arqueológicos. III Congreso de Arqueología Medieval Española II. Universidad de Oviedo, Oviedo, pp 406-412

Pascual J, Ribera A (1990) Plaça de L'Almoina. In: Excavaciones arqueológiques de selvament a la Comunitat Valenciana 19841988, 1, intervencions urbanes. Generalitat de Valencia, Valencia

Pascual J, Serrano ML (1996) Necrópolis islámicas en la ciudad de Valencia. Saitabi 46:231-252 
Peña-Chocarro L, Pérez-Jordà G, Alonso N, Antolín F, Teira-Brión A, Tereso JP, Moya EMM, Reyes DL (2017) Roman and medieval crops in the Iberian Peninsula: a first overview of seeds and fruits from archaeological sites. Quaternary International, In Press, https:// doi.org/10.1016/j.quaint.2017.09.037

Pestle WJ, Crowley BE, Weirauch MT (2014) Quantifying interlaboratory variability in stable isotope analysis of ancient skeletal remains. PLOS One 9(7):e102844

Pickard C, Girdwood LK, Kranioti E, Márquez-Grant N, Richards MP, Fuller BT (2017) Isotopic evidence for dietary diversity at the mediaeval Islamic necropolis of Can Fonoll (10th to 13th centuries CE), Ibiza, Spain. J Archaeol Sci Rep 13:1-10

Quirós Castillo JA (2013) Los comportamientos alimentarios del campesinado medieval en el País Vasco y su entorno (siglos VIIIXIV). Historia Agraria 59:13-41

Reitsema LJ, Kozłowski T, Crews DE, Katzenberg MA, Chudziak W (2017) Resilience and local dietary adaptation in rural Poland, 1000-1400 CE. J Anthropol Archaeol 45:38-52

Ribera A (2006) The Roman foundation of Valencia and the town in the 2nd-1st c. B.C. In: Abad L, Keay S \& Ramallo S (eds) Early Roman towns in Hispania tarraconensis (pp.75-90). Journal of Roman Archaeology Supplementary Series Number 62, Portsmouth, Rhode Island

Ribera A (2008) La ciudad de Valencia durante el periodo visigodo. Zona arqueológica 9:303-320

Richards MP, Fuller BT, Molleson TI (2006) Stable isotope palaeodietary study of humans and fauna from the multi-period (Iron Age, Viking and Late Medieval) site of Newark Bay, Orkney. J Archaeol Sci 33(1):122-131

Ruas M-P, Mane P, Hallavant C, Lemoine M (2017) Citrus fruit in historical France. Written sources, iconographic and archaeological remains. In: Zech-Matterne V, Fiorentino G (eds) AGRUMED: archaeology and history of citrus fruit in the Mediterranean. Publications du Centre Jean Bérard, Naples, pp 157-184

Rubio A (1995) El consumo de pan en la Valencia bajomedieval. Col.loqui d'història de l'alimentació a la Corona d'Aragó. Actes, Vol 1, pp 153-184

Ruiz TF (2014) Spanish society, 1400-1600. Routledge, London and New York

Salamon M, Coppa A, McCormick M, Rubini M, Vergiu R, Tuross N (2008) The consilience of historical and isotopic approaches in reconstructing the medieval Mediterranean diet. J Archaeol Sci 35(6):1667-1672

Salazar-García DC, Richards MP, Nehlich O, Henry AG (2014) Dental calculus is not equivalent to bone collagen for isotope analysis: a comparison between carbon and nitrogen stable isotope analysis of bulk dental calculus, bone and dentine collagen from same individuals from the medieval site of El Raval (Alicante, Spain). J Archaeol Sci 47:70-77

Salazar-García DC, Romero A, García-Borja P, Subirà ME, Richards MP (2016) A combined dietary approach using isotope and dental buccal-microwear analysis of human remains from the Neolithic, Roman and Medieval periods from the archaeological site of Tossal de les Basses (Alicante, Spain). J Archaeol Sci Rep 6:610 619

Scheuer L, Black S (2000) Developmental juvenile osteology. Academic Press, San Diego

Schoeninger MJ, DeNiro MJ (1984) Nitrogen and carbon isotopic composition of bone collagen from marine and terrestrial animals. Geochim Cosmochim Acta 48(4):625-639

Schoeninger MJ, DeNiro MJ, Tauber H (1983) Stable nitrogen isotope ratios of bone collagen reflect marine and terrestrial components of prehistoric human diet. Science 220(4604):1381-1383
Schwarcz HP, Schoeninger MJ (2011) Stable isotopes of carbon and nitrogen as tracers for palaeo-diet reconstruction. In: Baskaran $\mathrm{M}$ (ed) Handbook of environmental isotope geochemistry. SpringerVerlag, Berlin, pp 725-742

Schwarcz HP, Dupras TL, Fairgrieve SI (1999) ${ }^{15} \mathrm{~N}$ enrichment in the Sahara: in search of a global relationship. J Archaeol Sci 26(6): 629-636

Sealy J, Johnson M, Richards M, Nehlich O (2014) Comparison of two methods of extracting bone collagen for stable carbon and nitrogen isotope analysis: comparing whole bone demineralization with gelatinization and ultrafiltration. J Archaeol Sci 47:64-69

Serrano L (1997) Memoria preliminar de la intervención arqueológica situada en los solares $n^{\text {os }} 48$ al 58 de la Calle Alta Valencia. Ayuntamiento de Valencia, Valencia

Shatzmiller M (1994) Labour in the medieval Islamic world. Brill, Leiden

Sirignano C, Grau Sologestoa I, Ricci P, García-Collado MI, Altieri S, Quirós Castillo JA, Lubritto C (2014) Animal husbandry during Early and High Middle Ages in the Basque Country (Spain). Quat Int 346:138-148

Squatriti P (2014) Of seeds, seasons, and seas: Andrew Watson's medieval agrarian revolution forty years later. J Econ Hist 74(4):12051220

Tomás MS (2009) El uso terapéutico de la alimentación en la Baja Eded Media. In: Arízaga B, Solórzano JA (eds) Alimentar la ciudad en la Edad Media. Instituto de Estudios Riojanos, Logroño, pp 459-490

Torró J (2009a) Field and canal building after the conquest: modifications to the cultivated ecosystem in the Kingdom of Valencia, ca. 1250-ca. 1350. In: Catalos BA (ed) Worlds of history and economics. Universitat de Valencia, Valencia, pp 77-108

Torró J (2009b) Madîna Balansiya: la Valencia andalusí. Siglos VIII-XIII. In: Hermosilla Pla J (ed) La ciudad de Valencia, historia, geografía y arte de la ciudad de Valencia. Vol. 1: Historia. Universitat de Valencia, Valencia, pp 159-169

Torro J (2012a) One aspect of the Christian settlement of the Kingdom of Valencia: the drainage and placing under cultivation of coastal wetlands (c. 1270-1320). In: Galetti P (ed) Paesaggi, Comunità, Villaggi Medievali. Fondazione Centro Italiano di Studi Sull'Alto Medioevo, Spoleto, pp 225-237

Torró J (2012b) La conquista del Reino de Valencia. Un proceso de colonización medieval desde la Arqueología del territorio. In: Eiroa JA (ed) La conquista de al-Andalus en el siglo XIII. Editum-Centro de Estudios Medievales de la Universidad de Murcia, Murcia, pp 9-40

Triantaphyllou S, Richards MP, Zerner C, Voutsaki S (2008) Isotopic dietary reconstruction of humans from Middle Bronze Age Lerna, Argolid, Greece. J Archaeol Sci 35(11):3028-3034

Trillo San José C (1999) El paisaje vegetal en la Granada islámica y sus transformaciones tras la conquista castellana. Historia Agraria 17: 131-152

Turner BL, Edwards JL, Quinn EA, Kingston JD, Van Gerven DP (2007) Age-related variation in isotopic indicators of diet at medieval Kulubnarti, Sudanese Nubia. Int J Osteoarchaeol 17(1):1-25

Ubelaker DH (1989) Human skeletal remains: excavation, analysis, interpretation. Taraxacum, Washington

van Klinken G (1999) Bone collagen quality indicators for palaeodietary and radiocarbon measurements. J Archaeol Sci 26:687-695

Vassberg DE (1974) The 'Tierras Baldías': community property and public lands in 16th century Castile. Agric Hist 48(3):383-401

Waines D (1992) The culinary culture of al-Andalus. In: Jayyusi SK (ed) The legacy of Muslim Spain. Brill, Lieden, pp 725-740

Ward J (2002) Women in medieval Europe 1200-1500. Longman, Harlow

Watson AM (1974) The Arab agricultural revolution and its diffusion, 700-1100. J Econ Hist 34(1):8-35 